\title{
Stenorhynchosaurus munozi, gen. et sp. nov. a new pliosaurid from the Upper Barremian (Lower Cretaceous) of Villa de Leiva, Colombia, South America
}

\author{
María Eurídice Páramo-Fonseca ${ }^{1, *}$, Marcela Gómez-Pérez ${ }^{2}$, Leslie F. Noé2, Fernando Etayo-Serna ${ }^{3}$ \\ ${ }^{1}$ Departamento de Geociencias, Universidad Nacional de Colombia, Bogotá, Colombia \\ ${ }^{2}$ Departamento de Geociencias, Universidad de los Andes, Bogotá, Colombia \\ ${ }^{3}$ Servicio Geológico Colombiano, Bogotá, Colombia
}

\begin{abstract}
From one of the most complete Lower Cretaceous rock sequences in the world (in Villa de Leiva region, central Colombia), we describe a new genus and species of pliosaurid plesiosaur Stenorhynchosaurus munozi. Stenorhynchosaurus displays a series of features which differentiate it from all the other Cretaceous pliosaurid genera: the anterior of the vomer, in ventral view, posterior of the palatal premaxilla-maxilla suture, contacting the posterior palatal process of the premaxilla level with the third maxillary alveolus; rostrum narrow and elongated with straight sides in dorsal view; lacrimal forming the anterior border and greater part of the ventral border of the orbit and broadly borders the maxilla anteriorly; anterior interpterygoid vacuity present; internal nares located between vomer and maxilla at the level of $13^{\text {th }}-15^{\text {th }}$ maxillary alveoli; anterior of rostrum and mandible without lateral expansion or marked increase in size of the functional alveoli; penultimate premaxillary alveolus slightly larger than adjacent premaxillary alveoli; homodont maxillary functional alveoli, with fourth tooth positions very slightly enlarged with respect to the neighboring alveoli; homodont dentary dentition; and epipodials extremely short. Based on morphological analysis of phylogenetic characters, Stenorhynchosaurus most likely nests within the increasingly inclusive Pliosauridae and Pliosauroidea, however, as currently defined, firm inference for referral of Stenorhynchosaurus to Thalassophonea is much more problematic, but ultimately seems likely based on characters shared with Pliosaurus and Brachaucheninae. However, this uncertainty indicates Thalassophonea requires rigorous redefinition. As to whether Stenorhynchosaurus is a member of the currently exclusively Jurassic genus Pliosaurus, or the Cretaceous sub-family Brachaucheninae, remains equivocal.
\end{abstract}

Key words: Pliosauridae, Barremian, Lower Cretaceous, Colombia.

Stenorhynchosaurus munozi, gen. et sp. nov. un pliosaurido nuevo del barremiano superior (Cretácico Inferior) de Villa de Leiva, Colombia, Suramérica

\section{Resumen}

Se describe un nuevo género y especie de pliosáurido, Stenorhynchosaurus munozi, procedente de una de las secuencias de rocas del Cretácico Inferior más completas del mundo (en la región de Villa de Leiva, centro de Colombia). Stenorhynchosaurus exhibe una serie de características que lo diferencian de los demás géneros de pliosáuridos cretácicos: extremo anterior del vómer en vista ventral en posición posterior a la sutura palatal premaxilar-maxilar, contactando al proceso palatal del premaxilar al nivel del tercer alveolo maxilar; rostro angosto y alargado con lados rectos en vista dorsal; lagrimal formando el borde anterior y gran parte del borde ventral de la órbita y limitando ampliamente el maxilar anteriormente; cavidad inter-pterigoidea presente; narinas internas ubicadas entre el vómer y el maxilar, al nivel de los alvéolos 13 y 15; parte anterior del rostro y de la mandíbula sin expansión lateral o incremento marcado en el tamaño de los alvéolos funcionales; penúltimo alvéolo premaxilar ligeramente más grande que los adyacentes; alvéolos funcionales maxilares homodontes, el cuarto apenas más grande que los adyacentes; dentición dentaria homodonte; y epipodios extremadamente cortos. Con base en un análisis de caracteres filogenéticos, Stenorhynchosaurus corresponde con mayor seguridad a los cada vez más incluyentes Pliosauridae and Pliosauroidea, mientras la inferencia para referir Stenorhynchosaurus a Thalassophonea es más problemática, pero finalmente parece probable basada en caracteres compartidos con Pliosaurus y Brachaucheninae. Esta incertidumbre indica que Thalassophonea require de una redefinición rigurosa. Decir si Stenorhynchosaurus es un miembro del género Pliosaurus, por ahora exclusivamente jurásico, o de la subfamilia Brachaucheninae, es equívoco.

Palabras clave: pliosauridae, Barremiano, Cretácico Inferior, Colombia. 


\section{Introduction}

Worldwide, pliosaurids from the Lower Cretaceous are poorly represented in the fossil record. The Lower Cretaceous Paja Formation of Colombia (Hauterivian to Upper Aptian (Etayo-Serna, 1968) preserves a diverse fauna including pliosaurid plesiosaurs. In particular, the region of central Colombia around the town of Villa de Leiva preserves an exceptionally rich vertebrate fauna (Welles, 1962; Etayo Serna, 1968; Goñi y Gasparini, 1983; De la Fuente y Goñi, 1983; Hampe, 1992; Páramo, 1997; Cadena \& Parham, 2015), including the holotype of Kronosaurus boyacensis Hampe, 1992. A second pliosaurid specimen (Hampe, 2005), currently referred to Brauchauchenius sp., is the subject of this contribution. As detailed here, this second specimen (VL17052004-1) represents a new genus and species, for which the name Stenorhynchosaurus munozi, gen. et sp. nov. is here proposed. Additional pliosaurid specimens from the Paja Formation, some representing new genera and/or species, await formal description.

The aims of this study are to present a detailed description and comparative analysis of the principal morphological characteristics of Stenorhynchosaurus, which represents only the second Lower Cretaceous pliosaurid to be formerly described from the Villa de Leiva region of central Colombia. The holotype of Stenorhynchosaurus is well-preserved and substantially complete, and is thus of great significance for the global understanding of Lower Cretaceous pliosaurids, for the fossil heritage of northern South America, for our understanding of the fauna in the seas surrounding the dispersing continent of Gondwana, and for the Villa de Leiva region as a source of marine reptiles. This study indicates the Villa de Leiva region is a highly significant source area for marine vertebrate fossils, and a unique source of information for understanding the evolutionary history of Lower Cretaceous pliosaurids.

\section{Discovery, geological setting and stratigraphy}

In 2000, fragments of the anterior of a snout of a marine reptile were discovered in Barremian stage strata during excavation of a small dam on the property of Mr Jorge Muñóz, in the town of Villa de Leiva, central Colombia. The discovery was reported to the local authorities, who requested staff from the Museo Geológico José Royo y Gómez of the Colombian Geological Survey, INGEOMINAS (currently the Servicio Geológico Colombiano or SGC) to investigate. The excavation of the fossil was undertaken in 20042005, in collaboration with the Fundación Colombiana de Geobiología. During the excavation the skeleton was carefully documented in situ, and then extracted and transferred to the paleontological collections of the Servicio

\footnotetext{
*Corresponding author:

María Eurídice Páramo-Fonseca, meparamof@unal.edu.co

Received: June 5, 2015

Accepted: January 15, 2016
}

Geológico Colombiano in Bogotá, and registered under the number VL17052004-1. Subsequently, the skull was chemically prepared by the Fundación Colombiana de Geobiología. The collection and preparation of VL17052004-1 revealed a substantially complete, articulated pliosaurid skeleton lacking only the anterior of the rostrum, elements of the left anterior paddle, the right posterior paddle and the tail.

The pliosaurid VL17052004-1 was found at Loma La Cabrera, west of the town of Villa de Leiva (Figure 1S, http://www.raccefyn.co/index.php/raccefyn/article/ downloadSuppFile/239/1249) where the Lower Cretaceous Paja Formation is well exposed. The skeletal remains were found in 'Segmento C' (Etayo Serna, 1968) of the Arcillolitas Abigarradas Member of the Paja Formation (Figure 2S, http://www.raccefyn.co/index.php/raccefyn/article/ downloadSuppFile/239/1250), which is interpreted to have been deposited in an intertidal marine complex (Forero \& Sarmiento, 1985), an unusual depositional environment in which to find pliosaurid remains. The skeleton was found articulated in a variegated kaolinitic claystone (Light Brownish Gray 5YR6/1, Light Greenish Gray 5GY8/1 and Light Gray N7 (Rock-Color Chart Committee, 1963)) $0.6 \mathrm{~m}$ above a thin bed of argillaceous limestone with large, rusty-colored calcareous concretions (Moderate Reddish Brown 10R 4/6) that were up to $1 \mathrm{~m}$ in diameter and which show mud-cracked surfaces (Figure 3S, http://www.raccefyn.co/index.php/raccefyn/article/ downloadSuppFile/239/1251). Several ammonites were recovered from one of these concretions (SGC registered numbers MP-110804/1 and MP-250604/2a, b, c). One additional ammonite body fossil (MP-110804/2), along with several ammonite impressions from which latex moulds were made (MP-171108/1-5), were recovered from within the pliosaurid skull which was partly filled with fine calcareous matrix. Ammonite specimens and moulds are preserved in the collections of the Servicio Geológico Colombiano (SGC), Bogotá, Colombia.

\section{Biostratigraphic context}

The taxonomic identification of ammonite genera and species within the family Pulchelliidae Douvillé, 1890 follows Vermeulen (2003). According to Vermeulen (2003), the genus Gerhardtia Hyatt, 1903 includes the species G. sartousiana (D’Orbigny, 1841), G. provincialis (D’Orbigny, 1850), and G. galeatoides (Karsten, 1856). Only the latter two species have been documented from the Villa de Leiva region under different specific names (Vermeulen, 2003; Vermeulen \& Klein, 2006).

In the biostratigraphic zonation of the Barremian stage around Villa de Leiva, based on the family Pulchelliidae (Bürgl, 1956), Gerhardtia Hyatt, 1903 is treated as a subgenus of Heinzia Sayn, 1890. A similar taxonomic approach is followed by Patarroyo (2004). Bürgl stated: 'Heinzia (Gerhardtia) is restricted in Colombia to the upper 
part of the middle Barremian’ (translated from Bürgl, 1956). The Barremian ammonite zonation proposed by Patarroyo (2000, 2004) for the Villa de Leiva region includes the 'Heinzia (Gerhardtia) veleziensis Zone' which represents the lowest zone of the Colombian upper Barremian. However, Vermeulen (2003) synonymized Heinzia (Gerhardtia) veleziensis (Hyatt, 1903) and Heinzia (Heinzia) colleti Bürgl, 1956 with Gerhardtia galeatoides, and considered Carstenia lindigii (Karsten, 1856) as a synonym of Gerhardtia provincialis.

In the 'Heinzia (Gerhardtia) veleziensis-Zone', the ammonite assemblages recorded at Loma La Yesera and Loma de Monsalve in the Villa de Leiva region by Patarroyo (2000), contain the same species as those mentioned by Etayo Serna (1968), from a section in Loma la Cabrera, near where the pliosaurid was discovered. Hampe (2005: p. 38) referring to the pliosaurid discussed here wrote: "the age of the specimen [VL17052004-1] can be determined from numerous finds of the ammonite Heinzia sp. which are late Barremian in age (Patarroyo, 2000)”.

In situ ammonites from the mudcracked argillaceous limestone $0.6 \mathrm{~m}$ below the pliosaurid skeleton are wellpreserved internal moulds with rusty-colored weathering on their exposed surfaces; they are identified as $G$. galeatoides (Karsten, 1856) (MP-250604/2a, c) (Figure 4S a, b and c, http://www.raccefyn.co/index.php/raccefyn/ article/downloadSuppFile/239/1252), and G. provincialis (D’Orbigny, 1850) (MP-110804/1, MP-110804/3, MP250604/2b) (Figure 4S d, e, f and g). The ammonite body fossil (MP-110804/2), and specimens now preserved as latex casts (MP-171108/1, 2) (Figure 4S h, i and j) recovered from the calcareous infilling of the pliosaurid skull are identified as G. galeatoides (Karsten, 1856) [ammonite determinations undertaken by F.E.-S.].

The ammonite zonation of the French Barremian (Vermeulen, 2003) has in part has been adopted by the IUGS (Reboulet \& Hoedemaeker, 2006; Reboulet, et al., 2014), and was used here to estimate the age of the pliosaurid bearing beds. The two ammonite species G. galeatoides and G. provincialis, collected both below and within the skull of the pliosaurid, permits recognition of the Gerhardtia provincialis Subzone of the Gerhardtia sartousiana Zone of the lower part of the upper Barremian (i.e. early late Barremian) of the scheme adopted by the IUGS (Reboulet \& Hoedemaeker, 2006: Reboulet, et al., 2014).

\section{Nomenclatural acts}

This publication, including the electronic version, conforms to the requirements of the current International Code of Zoological Nomenclature (ICZN), with the new taxon available under the Code from the date of publication. This publication, and the nomenclatural act contained herein, has been registered in ZooBank, the ICZN online registration system for new taxa. The ZooBank Life Science
Identifier (LSID) for this publication is urn:lsid:zoobank. org:pub:7CBB6FCD-5242-4A49-B489-3425D54264AE and the LSIDs for the new taxon are given under the Systematic paleontology section (below); all LSIDs can be viewed online at http://zoobank.org/.

\section{Systematic paleontology}

SAUROPTERIGIA Owen, 1860

PLESIOSAURIA de Blainville, 1835

PLIOSAUROIDEA Welles, 1943

PLIOSAURIDAE Seeley, 1874

Stenorhynchosaurus gen. nov.

urn:Isid:zoobank.org:act:558CC1C6-D0EF-4E84-9A35233B97A60E7A

Type and only species: Stenorhynchosaurus munozi, sp. nov.

Type Locality: Loma La Cabrera, Villa de Leiva, Boyacá,

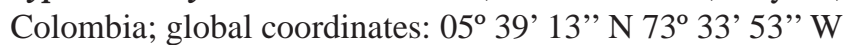
(Figure 1S).

Stratigraphical horizon: Arcillolitas Abigarradas Member, Paja Formation. Lower part of the Upper Barremian, Lower Cretaceous (Figure 2S).

Derivation of name: Greek Stenos, narrow; Rhyncho, snout; and Saurus, lizard.

Diagnosis: As for type and only known species.

Stenorhynchosaurus munozi sp. nov.

urn:Isid:zoobank.org:act:361CC851-5B23-4D8B-821173D6F6BA941E

Holotype: VL17052004-1, a nearly complete pliosaurid skeleton, lacking fragments of the left anterior paddle, the right posterior paddle and the tail (Figure 1). The specimen repository is the paleontological collections of the Museo Geológico José Royo y Gómez, Servicio Geológico Colombiano (SGC).

Derivation of name: The specific name S. munozi is proposed in honor of Jorge Muñoz who discovered and reported the find of the pliosaurid on his land, and handed VL170520041 to the collections of the Museo Geológico José Royo y Gómez, Servicio Geológico Colombiano.

Diagnosis: The pliosaurid Stenorhynchosaurus munozi (VL17052004-1) distinguished from all other pliosaurids in having in ventral view the anterior end of the vomer posterior of the palatal premaxilla-maxilla suture (at the level of the second maxillary alveolus) and contacting ventrally the posterior palatal process of the premaxilla at the level of the third maxillary alveolus, together with the following unique combination of characters: narrow rostrum elongated, with practically straight sides in dorsal view; lacrimal forms the anterior border and greater part 

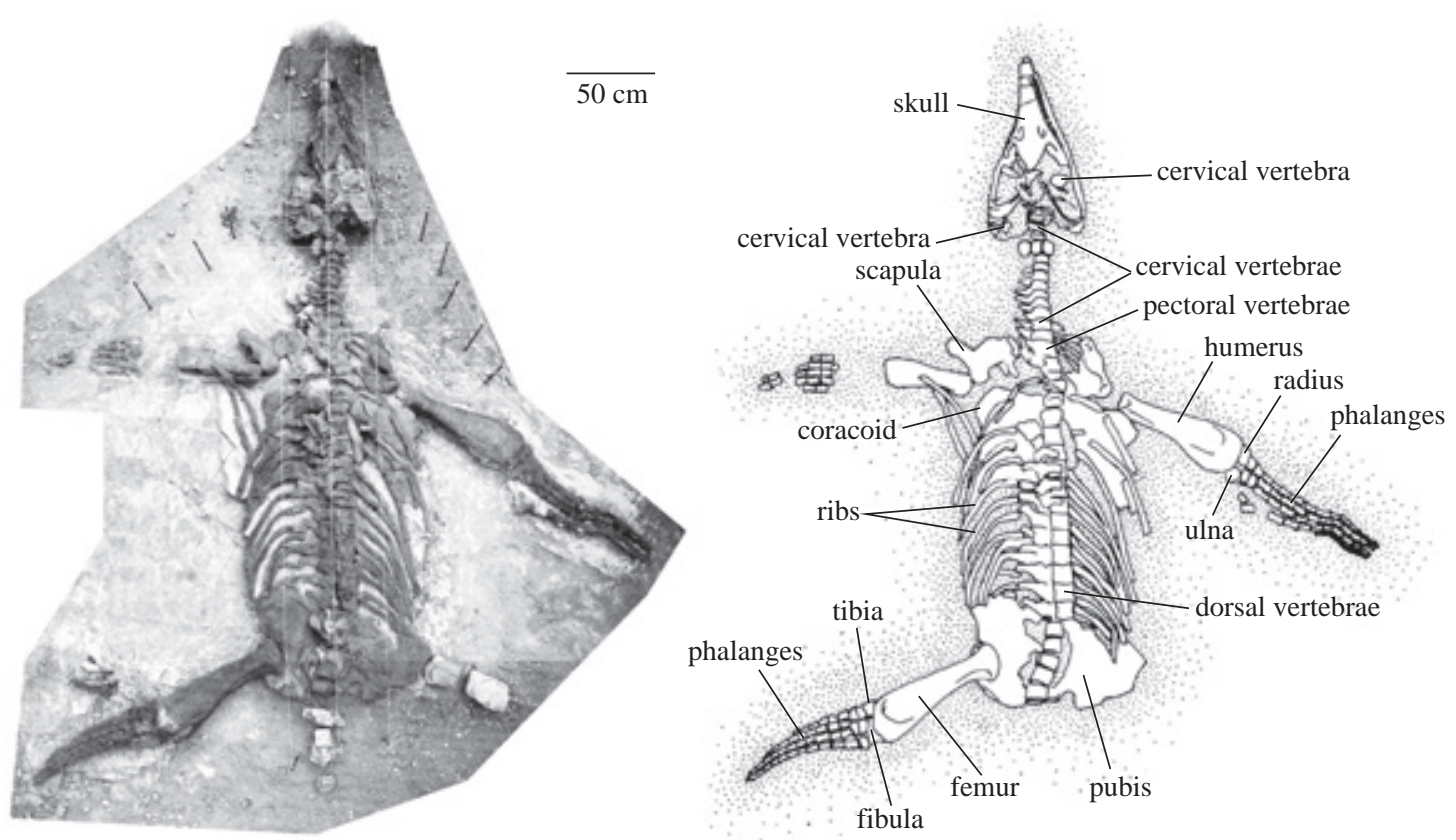

Figure 1. VL17052004-1, holotype specimen of Stenorhynchosaurus munozi gen. and sp. nov. General view of the specimen in dorsal view. Photography in the field and interpretation of the skeleton.

of the ventral border of the orbit and broadly borders the maxilla anteriorly; anterior interpterygoid vacuity present; internal nares located between vomer and maxilla at the level of $13^{\text {th }}-15^{\text {th }}$ maxillary alveoli; anterior of rostrum and mandible without lateral expansion or marked increase in size of the functional alveoli; penultimate premaxillary alveolus slightly larger than adjacent premaxillary alveoli; at least 29, approximately homodont maxillary functional alveoli, with the fourth tooth positions very slightly enlarged with respect to the neighbouring alveoli; 32 to 34 approximately homodont dentary tooth positions; at least 17 cervical vertebrae, counting the absent atlas-axis complex as two vertebrae; cervical vertebrae with a single costal facet that extends anteroposteriorly almost along the full length of the vertebral body (but possibly an ontogenetic feature); epipodials extremely short.

Ontogenetic stage: We interpret Stenorhynchosaurus munozi (VL17052004-1) as a juvenile individual of the new pliosaurid genus Stenorhynchosaurus. The interpretation of juvenile characteristics is based on those proposed by Brown (1981) for plesiosaurian (long-necked) plesiosaurs as indicative of ontogenetic state, which include: the fully formed teeth that do not exhibit noticeable striations on the enamelled crown, whereas the crowns of replacement teeth exhibit enamel ridges which are not particularly prominent; articular facets of the vertebral centra gently concave, or almost flat; ribs on cervical centra unfused; ventral process of the scapulae separated; absence of a pectoral bar; undifferentiated capitulum and tuberosity or trochanter.
In addition, there are several additional traits that suggest a juvenile ontogenetic stage for Stenorhynchosaurus, which include an unsutured union between the majority of skull bones, including: the palatal union of the pterygoids between the anterior and posterior interpterygoid vacuities which is not sutured; the parasphenoid not sutured to the pterygoids anteriorly; the mandibular symphysis widely open, and with an especially large post symphyseal vacuity (see description). In addition, the neurocentral joint between cervical and dorsal vertebral centra and neural arches are not sutured; girdle bones articular facets are rounded and not well-marked.

\section{Description}

Preservation. The skeleton of Stenorhynchosaurus munozi (VL17052004-1) (Figure 1) is substantially complete, only lacking the anterior of the snout, elements of the left anterior paddle, the entire right posterior paddle and the tail; representative measurements of Stenorhynchosaurus are presented in Tables 1 and 2. The skeleton was found articulated, lying dorsal surface uppermost with the paddles laterally spread. The posterodorsal region of the cranium is crushed, some ribs are displaced from their original positions, and the neural arches are crushed down onto the vertebral column and adjacent elements. These taphonomic modifications to the skeleton seem to be the consequence of pre-burial (biostratinomic) processes. There is no evidence for predation or post-mortem scavenging of the carcass. Few elements of the right hind paddle and the tail were found separated from the skeleton by a short distance. On the base of the litological characteristics of the setiments, 
Table 1. General measurements (in centimetres) taken on the preserved material.

\begin{tabular}{lc}
\hline General length of the specimen at the middle line & 390 \\
\hline Total length of the skull at the middle line & 113 \\
\hline Total length of the skull to the posterior border of quadrates & 136 \\
\hline Width of the skull at the anterior border of the orbits & 30 \\
\hline Width of the skull at the external borders of the base of quadrates & 58 \\
\hline Width between the two orbits (at the anterior border of orbits) & 18 \\
\hline Length between posterior border of the external naris and & 4 \\
\hline anterior border of the orbit & 7.5 \\
\hline Length between internal naris and external naris & 9.5 \\
\hline Width between external nares & 9.5 \\
\hline Length of the external naris & 4.5 \\
\hline Width of the external naris & 148 \\
\hline Length of the anterior paddle & 157.5 \\
\hline Length of the posterior paddle & 66.5 \\
\hline Length of the humerus & 81 \\
\hline Length of the femur & 54 \\
\hline Maximal length of the coracoid & 36 \\
\hline Maximal width of the coracoid & 55 \\
\hline Maximal length of the pubis & 38 \\
\hline Maximal width of the pubis & \\
\hline
\end{tabular}

Table 2. Dimensions (in millimetres) of some vertebral centra from the articulated series.

\begin{tabular}{lccc}
\hline Articulated centra & Length & Height & Width \\
\hline $1^{\text {st }}$ & 44 & $70-74$ (by deformation) & 90 \\
\hline $2^{\text {nd }}$ & 45 & 75 & 100 \\
\hline $6^{\text {th }}$ & 42 & 72 & 92 \\
\hline $11^{\text {th }}$ & 44 & 73 & 95 \\
\hline Separated cervical centrum & 40 & 75 & 95 \\
\hline Separated cervical centrum & 45 & $?$ & 90 \\
\hline $18^{\text {th }}$ & 70 & 75 & 98 \\
\hline $27^{\text {th }}$ & 73 & $?$ & 100 \\
\hline $30^{\text {th }}$ & 80 & $?$ & 100 \\
\hline $36^{\text {th }}$ & 70 & 83 & 100 \\
\hline
\end{tabular}

a paleochannel is interpreted to have washed away these elements. The anterior of the snout was broken and lost when the fossil was discovered. Besides these taphonomic modifications previously described the bones generally exhibit a good state of preservation.

Skull (Figures 1 to 6 and figura 5S, http://www.raccefyn.co/ index.php/raccefyn/article/downloadSuppFile/239/1253) The skull lacks the anterior of the snout (i.e. both the upper and lower jaws) and most of the posterior skull roof. The pre-orbital rostrum of the cranium as preserved is considerably elongated and somewhat posteriorly expanded producing a triangular shape to the cranium in dorsal view; the rostrum is straight sided in lateral and dorsal views. The total length of the skull as preserved is two and a half times the width between the quadrates. The external nares lie at approximately the middle (anteroposteriorly) of the skull, $470 \mathrm{~mm}$ from the occipital condyle, and $560 \mathrm{~mm}$ from the posterior borders of quadrates; they are large and situated closely anterior to the orbits. The bones of the posterodorsal region of the skull are broken and poorly preserved, so the outline of the orbits and temporal fenestrae cannot be established with certainty.

Each premaxilla is incomplete and runs posteriorly along the dorsal surface of the snout forming a narrow bar between the maxilla and frontal. Anteriorly, the premaxilla-maxilla suture interdigitates deeply as it rises up the lateral surface of the snout, and more posteriorly smooths to delineate the lateral border of the premaxilla facial process. The posterior limits of the premaxillae are unclear on both sides of the skull due to poor preservation. Various foramina open on the anterior, external surface of the premaxillae laterally. A diastema of $30 \mathrm{~mm}$ in length separates the third and fourth preserved functional alveoli; the diastema is crossed by the premaxillamaxilla suture. On the palatal surface the premaxilla exhibits a long palatal process that extends posteriorly of the diastema, to level with the third maxillary functional alveoli. Dorsally, the palatal processes of premaxillae are separated ('deep') by an anterior prolongation of the vomers that runs anteriorly at least to the level of the second maxillary functional alveoli (Figures $4 \mathrm{c}$ and d). The premaxilla palatal processes thereby anatomically underlap the ventral surface of the anterior of the vomers as in Liopleurodon (Noè, 2001) and most probably all pliosaurids.

The maxilla forms the lateral surface of the pre-orbital rostrum dorsally; the anterior, ventral, and dorsal borders of the external naris, as is typical of the Brachaucheninae (Williston, 1907; Schumacher, et al., 2013); and extends posteriorly to form the ventral border of the orbit. The maxilla exhibits various foramina on the lateral surface, with three larger foramina aligned over the alveolar border anterior of the orbit. Ventrally the maxilla houses the posterior upper dentition, with the alveolar row bounded medially by a longitudinal ridge. Between this ridge and the palate is a marked longitudinal groove which contained the dental lamina in life, and where the posteromedially positioned replacement teeth are lodged. Medial to the middle of the fifth pair of maxillary functional alveoli there is a small rounded pit bordering the maxilla-vomer suture (Figures $4 \mathrm{c}$ and $\mathrm{d}$ ).

The dorsal surface and sutural contacts of the frontal are not well-preserved (Figure 2). There is no possible to establish the presence of an independent nasal. Lateral to the frontal, there are distinct bone textures that suggest the presence of a prefrontal and postfrontal, the limits of which cannot be established with certainly. However, the frontal appears to 

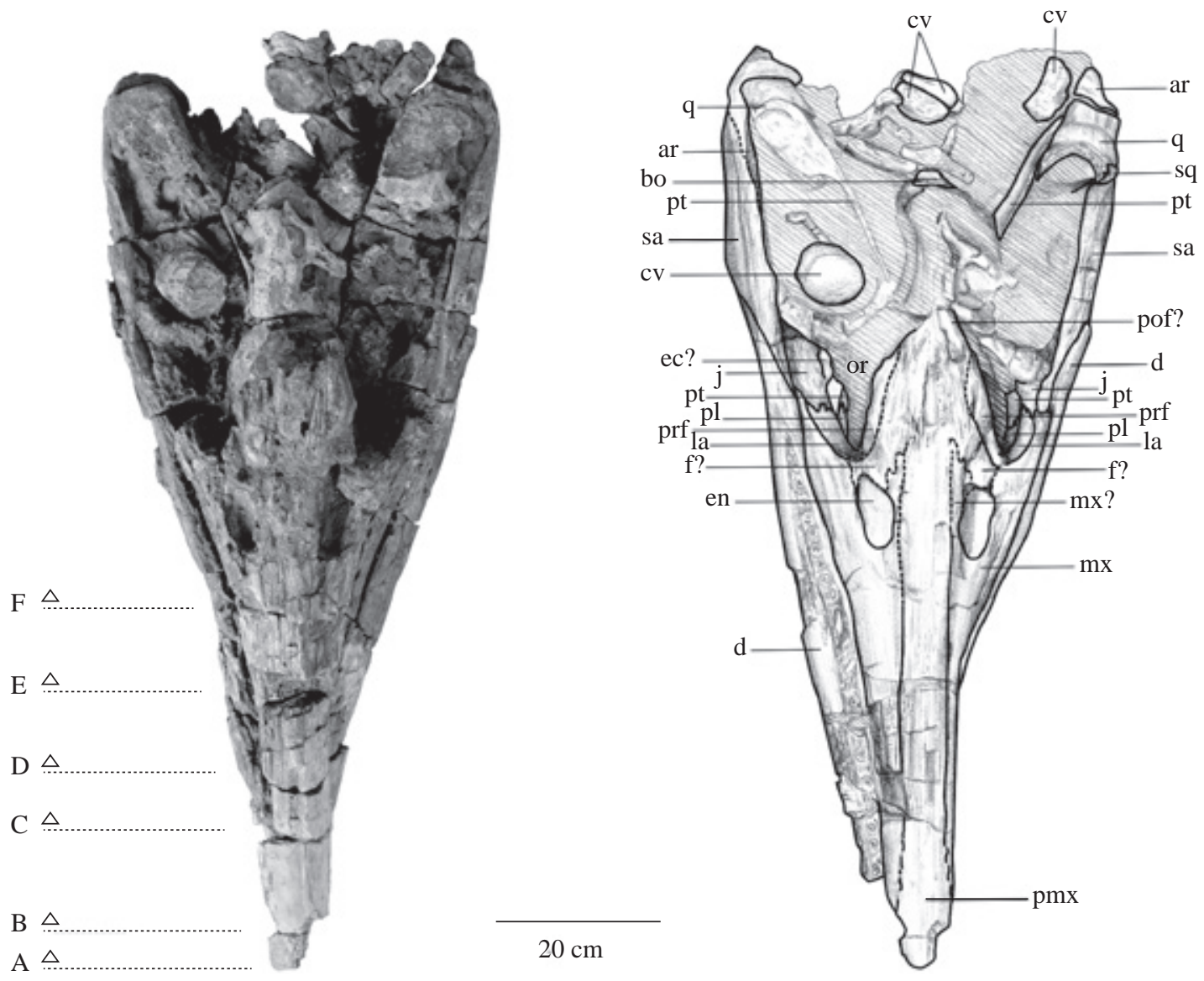

Figure 2. VL17052004-1, holotype specimen of Stenorhynchosaurus munozi gen. and sp. nov. Skull, dorsal view; A to F: snout cross sections represented in Figure 5. Abbreviations: ar, articular; bo, basioccipital; cv, cervical vertebra; d, dentary; ec, ectopterygoid; en, external naris; f, frontal; j, jugal; la, lacrimal; mx, maxilla; or, orbit; pl, palatine; pmx, premaxilla; pof, postfrontal; prf, prefrontal; pt, pterygoid; q, quadrate; sq, squamosal.

be excluded from the orbital margin by the prefrontal and postfrontal. The posterior of the parietal and the majority of the squamosal are not preserved, and the pineal foramen cannot be identified. On the right of the skull the bones forming the anterior of the orbit are preserved. The lacrimal forms the anteroventral border of the orbit and the palatine the floor of the orbit (Figure 3). Along the posterior of the ventral margin of the orbit, the posterior of the lacrimal contacts the anterior of the jugal (Figure 3), however, the bones forming the remainder of the posterior of the orbital rim are broken and cannot be distinguished. The damage to this region of the skull does not allow confident reconstruction of the form of the rear of the orbit or the temporal fenestra.

The palate (Figure 4) is well exposed, although posteriorly it is partly obscured by the well-preserved hyoids. The palate exhibits two interpterygoid vacuities: the anterior interpterygoid vacuity is lanceolate with a pointed anterior and a more rounded posterior margin; the posterior interpterygoid vacuity is more rounded with a slightly pointed anterior end, and is divided longitudinally by the parasphenoid, as is usual in plesiosaurs (Andrews, 1910,
1913). The two interpterygoid vacuities are connected by the unfused junction between the pterygoids, an indication of the juvenile status for Stenorhynchosaurus.

The conjoined vomers run medially between the premaxillae anteriorly and the maxillae posteriorly. In ventral view they extend from level with the second maxillary functional alveoli to form the anterior margins of the anterior interpterygoid vacuity posteriorly. In ventral view the anterior of the vomers lies posterior to the diastema, which is crossed by the premaxilla-maxilla suture. Anteriorly, the vomers are fused into an elongated bar that sends a very narrow process anterodorsally over the medial line of the premaxillae to a level with the ultimate premaxillary functional alveoli (Figure $5 \mathrm{~b}$ ). Posterior of the ninth maxillary functional alveoli, the vomers widen and exhibit a clear median suture, an indication of the juvenile ontogenetic status of the specimen. The midline vomer suture runs for a short distance more anteriorly on the dorsal ('deep') surface than can be observed on the palatal surface (Figure $5 \mathrm{~b}$ ). The lateral borders of the vomers, level with the $13^{\text {th }}$ to $15^{\text {th }}$ maxillary functional alveoli, form the medial margins of the 

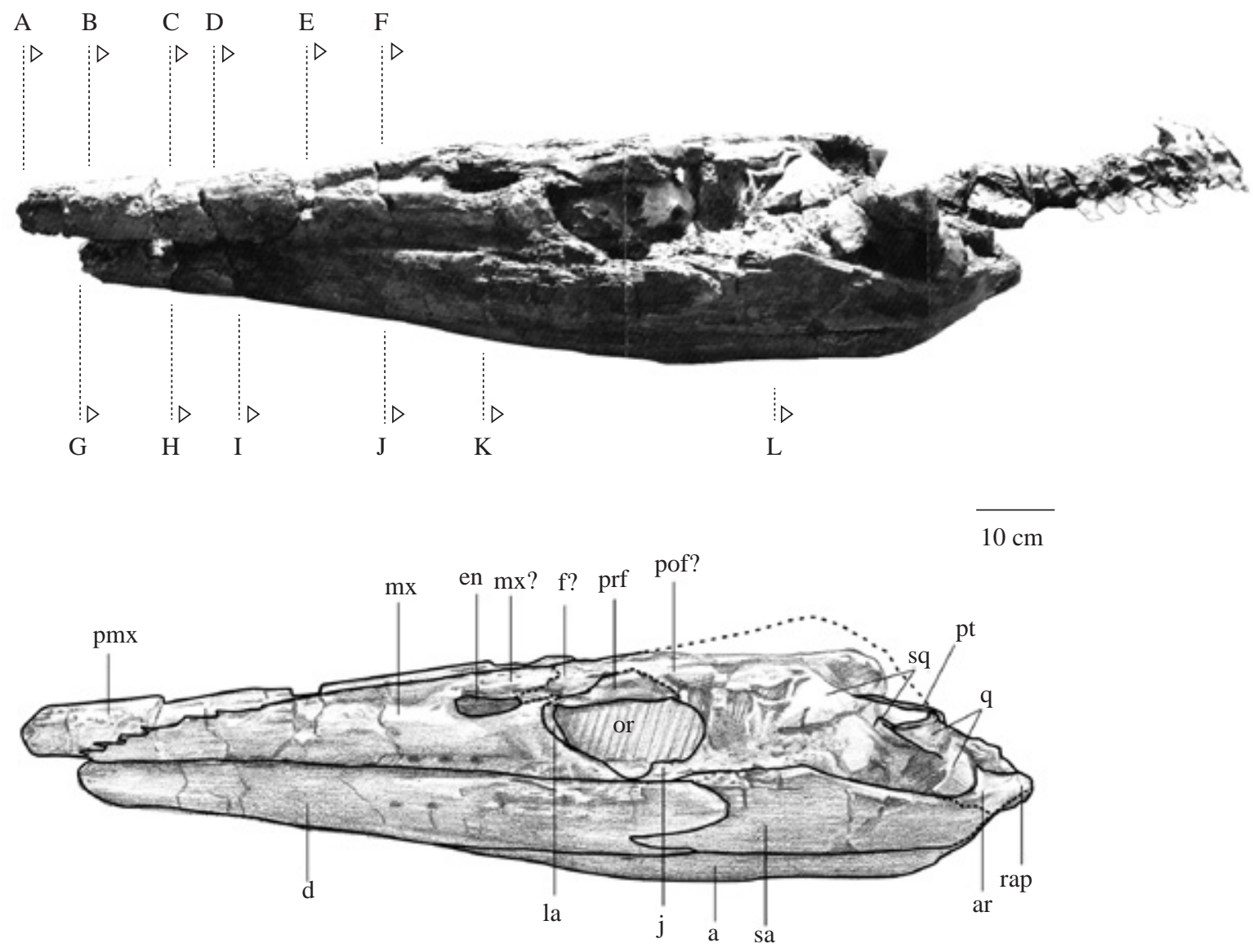

Figure 3. VL17052004-1, holotype specimen of Stenorhynchosaurus munozi gen. and sp. nov. Skull in left lateral view; A to F: snout cross sections represented in Figure 5; G to L: mandible cross sections represented in Figure 6. Abbreviations: a, angular; ar, articular; d, dentary; en, external naris; f, frontal; j, jugal; la, lacrimal; mx, maxilla; pmx, premaxilla; pof, postfrontal; prf, prefrontal; pt, pterygoid; q, quadrate; rap, retroarticular process; sa, surangular; sq, squamosal.

internal nares, the lateral margins formed by the maxillae. The posterior of the vomers is separated medially by the pointed anterior margin of the interpterygoid vacuity, and more laterally are overlain by a pointed prolongation of the pterygoid. Still further laterally the vomer contacts the palatine in an interdigitating suture, with the posteriormost projection of the suture bordering a small palatine opening (Figures $4 \mathrm{~b}$ and $\mathrm{c}$ ).

Several natural breaks across the snout of Stenorhynchosaurus show the internal morphology of the rostrum (Figure 5). A large rostral cavity can be observed similar to those in Libonectes morgani (Carpenter, 1997), Rhomaleosaurus megacephalus (now Atychodracon megacephalus Smith, 2015) (Cruickshank, 1994) and other pliosaurids (Buchy, et al., 2006). In Stenorhynchosaurus, immediately posterior to the internal nares, a dorsal vomeropalatine process is present (Figure $5 \mathrm{f}$ ), in agreement with Cruickshank, et al. (1991), but in contrast to Buchy, et al. (2006).

Both palatines are incomplete. The right palatine is wellexposed, but the posterior is not preserved (Figure $4 \mathrm{c}$ ). Each palatine exhibits an elongated rectangular shape, bordered medially by the pterygoid, laterally by the maxilla and anteriorly by the vomer. The palatine does not reach the margin of the internal naris on the palatal surface. Anteromedially the palatine has a process contacting, and lying ventral to the vomer for a short distance. Two small foramina perforate the palatal surface of each palatine: one lying on the posteriormost extent of the vomer-palatine suture; the other located more posteromedially along the suture with the pterygoid level with the posterior of the anterior interpterygoid vacuity. The posteromedial contact of the palatine with the anterior ramus of the pterygoid runs in an arc laterally and interdigitates considerably. Laterally, the suture with the maxilla forms an almost straight, but continuously interdigitating line.

The pterygoids form a great proportion of the palatal surface (Figure $4 \mathrm{c}$ ). The anterior rami are triangular in shape, sharply-pointed anteriorly, and medially separated by the narrow anterior interpterygoid vacuity. The anterior ramus of the pterygoid contacts the vomer, excluding the palatines from contact along the ventral midline. Medially the pterygoids are united through a slightly open suture between 
(a)

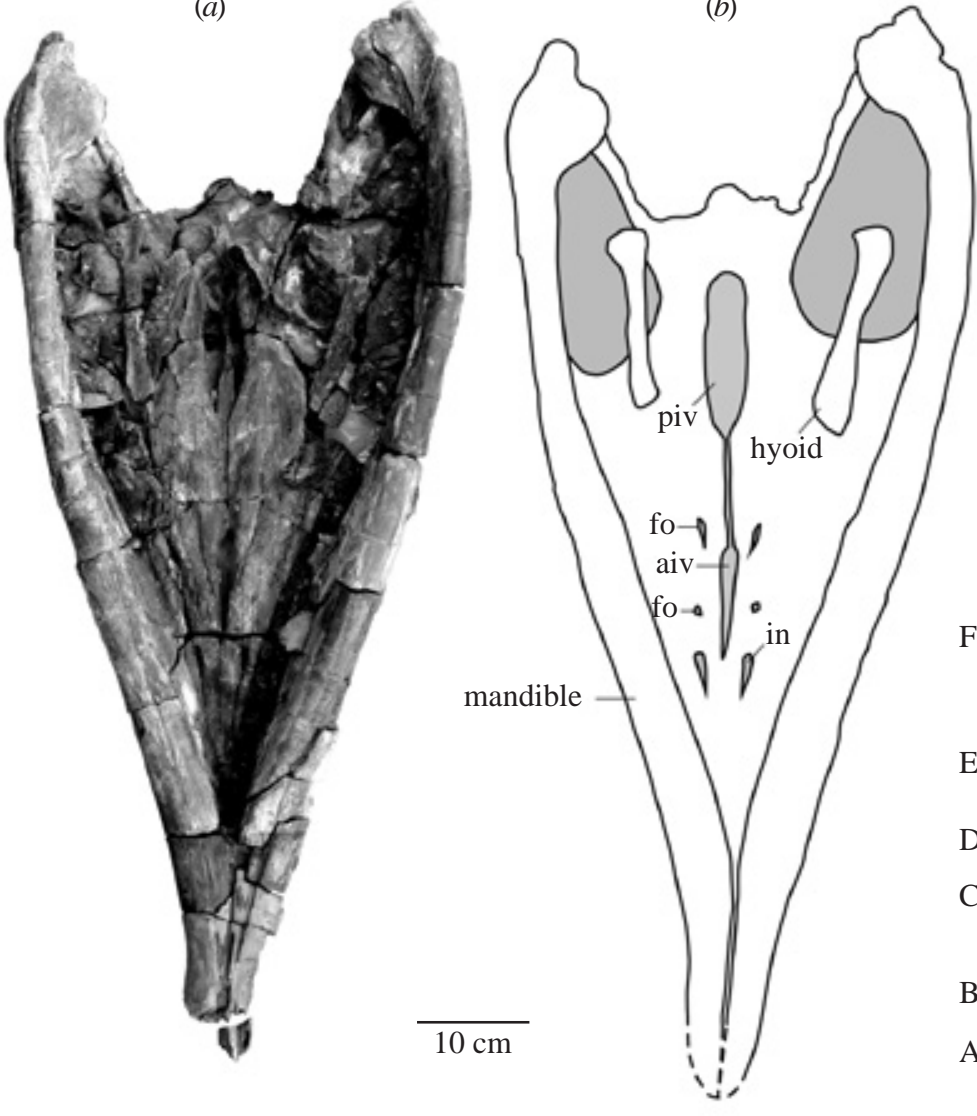

(b)

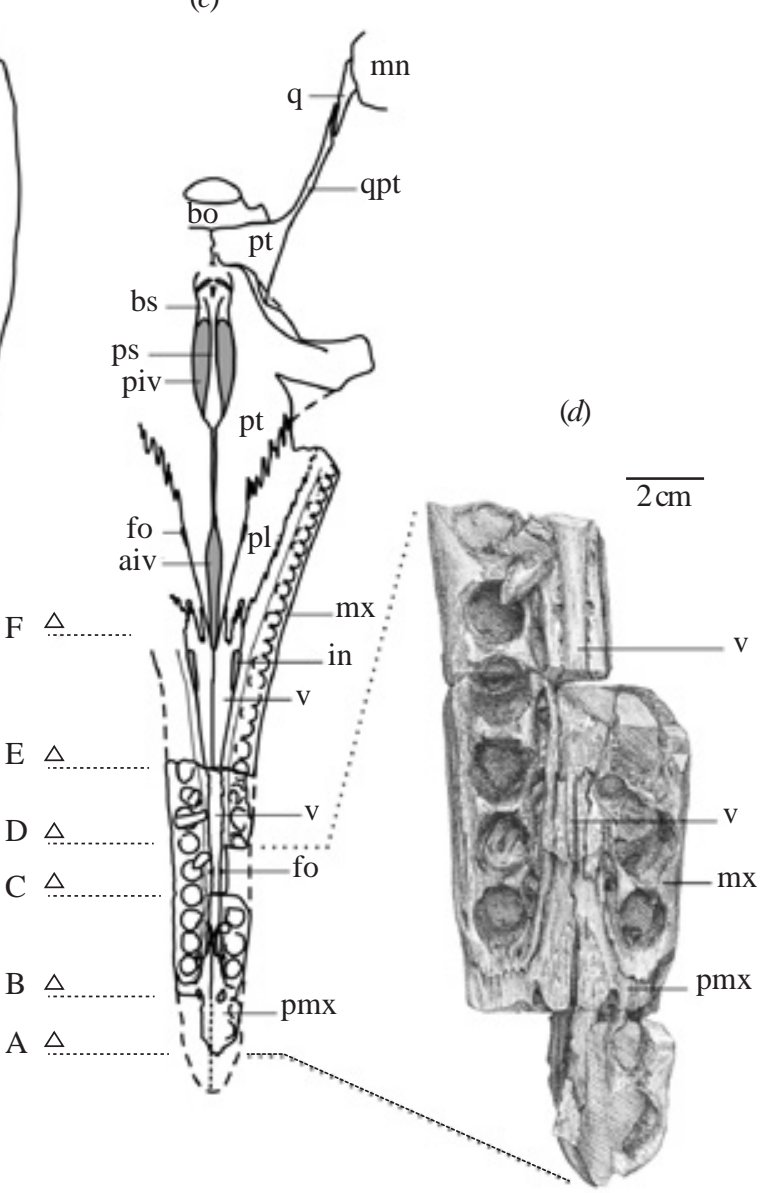

Figure 4. VL17052004-1, holotype specimen of Stenorhynchosaurus munozi gen. and sp. nov. $a$ and $b$ : Skull in palatal view. $c$ and $d$ : details of the palate without mandibles; A to F: snout cross sections represented in Figure 5. Abbreviations: aiv, anterior interpetrygoid vacuity; bo, basioccipital; bs, basisphenoid; fo, foramen; in, internal naris; mn, mandible; mx, maxilla; piv, posterior interpterygoid vacuity; pl, palatine; pmx, premaxilla; ps, parasphenoid; pt, pterygoid; q, quadrate; qpt, quadrate ramus of the pterygoid; v, vomer.

the anterior and posterior interpterygoid vacuities, but are well-sutured beneath the braincase, posterior of the posterior interpterygoid vacuity. Laterally each pterygoid contacts the palatine in an oblique suture that is straight anteriorly but interdigitates posteriorly. The straight anterior part of the pterygoid-palatine suture forms an elongated foramen immediately posterior of the level of the posterior border of the anterior interpterygoid vacuity.

The lateral ramus of the pterygoids is damaged and cannot be completely described. The contact between the pterygoid and ectopterygoid is covered by the hyoid elements on both sides of the palate. The anterior border of the lateral ramus of the pterygoid is broken on both sides of the cranium, suggesting a fragile condition in this region, and which precludes description of the morphology of the ectopterygoid. However, the lateral ramus does bear a prominent crest, the pterygoid flange, bordering its posterior edge that terminates near the midline of the skull just posterior of the posterior interpterygoid vacuities. The pterygoid flange is broken, although it reaches about 70 $\mathrm{mm}$ in height in the vicinity of the posterior interpterygoid vacuity. Laterally the ectopterygoid process of the pteygoid curves dorsally. Posterior of the posterior interpterygoid vacuity the pterygoids cover the basioccipital-basisphenoid junction ventrally. Posteriorly the occipital condyle and part of the body of the basioccipital are visible. Each quadrate ramus of the pterygoid is relatively wide beneath the braincase. Posteriorly, the quadrate ramus forms a subvertical lamina that extends obliquely laterally from a level anterior of the occipital condyle, the ventrolateral process of the basioccipital and terminates posteriorly in a contact with the medial edge of the quadrate laterally.

Within the posterior interpterygoid vacuity, the anterior of the basisphenoid and a part of the parasphenoid are visible (Figure $4 \mathrm{c}$ ). The anterior of the basisphenoid forms the posterior border of the posterior interpterygoid vacuity, which is divided longitudinally by the parasphenoid. The parasphenoid is a narrow, ventrally flattened bar that widens anteriorly. The ventral surface of the parasphenoid is covered anteriorly by the medial union of the pterygoids, 
A

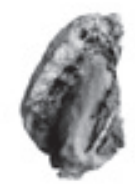

B

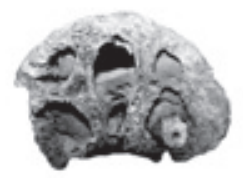

C

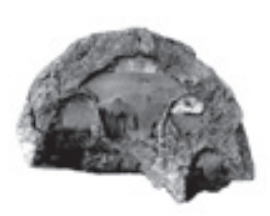

E

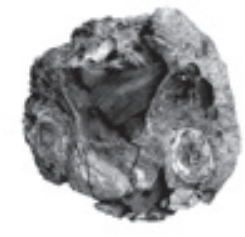

D

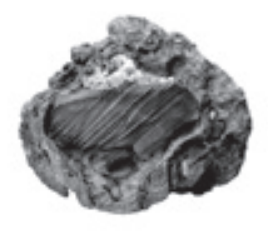

$\mathbf{F}$

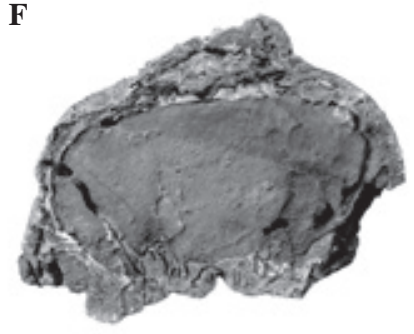

\section{$\overline{10 \mathrm{~cm}}$}
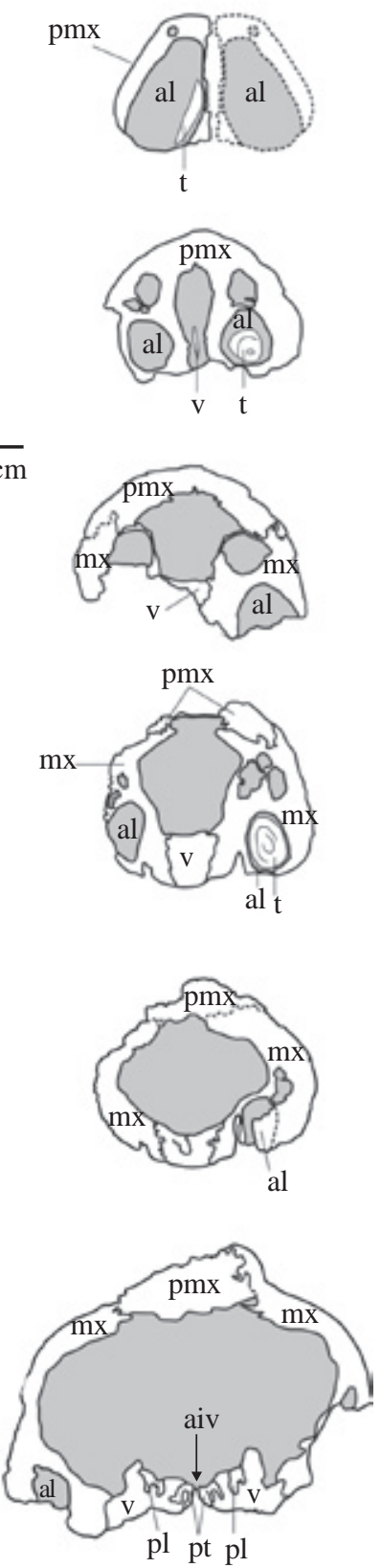

Figure 5. VL17052004-1, holotype specimen of Stenorhynchosaurus munozi gen. and sp. nov. Snout cross sections indicated in Figures 2, 3 and 4, looking from anterior view. Abbreviations: aiv, anterior interpetrygoid vacuity; al, alveolus; mx, maxilla; pmx, premaxilla; pl, palatine; pt, pterygoid; t, tooth; v, vomer.

however, there is no sutured contact visible between these bones. The basisphenoid-parasphenoid contact is also not visible. It is possible the parasphenoid runs posteriorly along the midline underlying the basisphenoid but without reaching the posterior ramus of the pterygoid. Posteriorly, at the contact with pterygoids, the basisphenoid bears a small median longitudinal crest ventrally. In occipital view the basioccipital exhibits a sub-circular condyle and one of the basioccipital basitubera, which is robust and long. The

dorsal surface of the basioccipital, normally forming the floor of the foramen magnum, and any ventral constricting ring and/or ventral plate are not preserved.

The quadrate has the form of an inclined slightly robust column with a posteriorly convex, semi-circular crosssection, terminating ventrally in a strong, transverse condyle. A few bone fragments found posterior of the basioccipital condyle are not clearly recognizable, but seem to be fragments of the squamosals, paraoccipital processes and atlas-axis complex, displaced from their original positions. One disarticulated and worn cervical centrum and a few cervical rib fragments can also be distinguished. Another poorly preserved cervical centrum is present inside the right temporal fenestra.

Ventrally overlying the palate, and extending slightly obliquely laterally, are two large, stout bones interpreted as hyoid elements. The preserved hyoids are both elongate, approximately $270 \mathrm{~mm}$ in length, and vaguely dumb-bell shaped.

Mandible (Figures 3, 4, 6 and 5S). The mandibular rami are preserved slightly offset from their original positions. The right ramus has moved laterally so the alveolar row is visible in dorsal view, and the left ramus has been displaced medially so the tooth row is covered by the rostrum. The mandible is slender in the anterior part and relatively high posteriorly. Anteriorly, along the midline, the two halves of the mandible are not in contact, but are separated by a space of approximately $10 \mathrm{~mm}$ dorsally and $3 \mathrm{~mm}$ ventrally (Figure 5S). However, the splenial (ventrally) and dentary (dorsally) lie adjacent to one another for a length of $230 \mathrm{~mm}$. This parallel space is thus the unsutured mandibular symphysis, which is normally fused in pliosaurids (e.g. Andrews, 1913; Noè, 2001; Sassoon, et al., 2012), the open suture corroborating the inferred juvenile ontogenetic stage of Stenorhynchosaurus. Alternatively the unfused mandibular symphysis may be a feature of some or all members of the Brachauchenininae (e.g. Schumacher, et al. 2013).

Although the length of the mandibular symphysis remains conjectural, the narrow anterior of the mandible, the presence of the premaxilla-maxilla suture in the rostrum, and the anterior inclination of the first preserved premaxilla functional alveolus, all indicate proximity to the anterior of the snout. Level with the anterior of the splenial there is a slight lateral constriction, indicating a very slightly spatulate anterior termination to the mandible. Mandibular fragments from Pliosaurus indicate the symphysis is longer ventrally than dorsally, with a parallel space between the two mandibular rami on the dorsal surface (Bardet, et al., 1993), similar to a space observed in Stenorhynchosaurus. A large opening occurs in the lingual surface of each mandibular ramus between the splenial and coronoid, opening anteriorly into Meckel's canal (Figures $6 \mathrm{~b}$ and d). This opening was probably present in all plesiosaurs and in Stenorhynchosaurus is as long as nine dentary functional alveoli; however, the large size is probably an ontogenetic feature. 


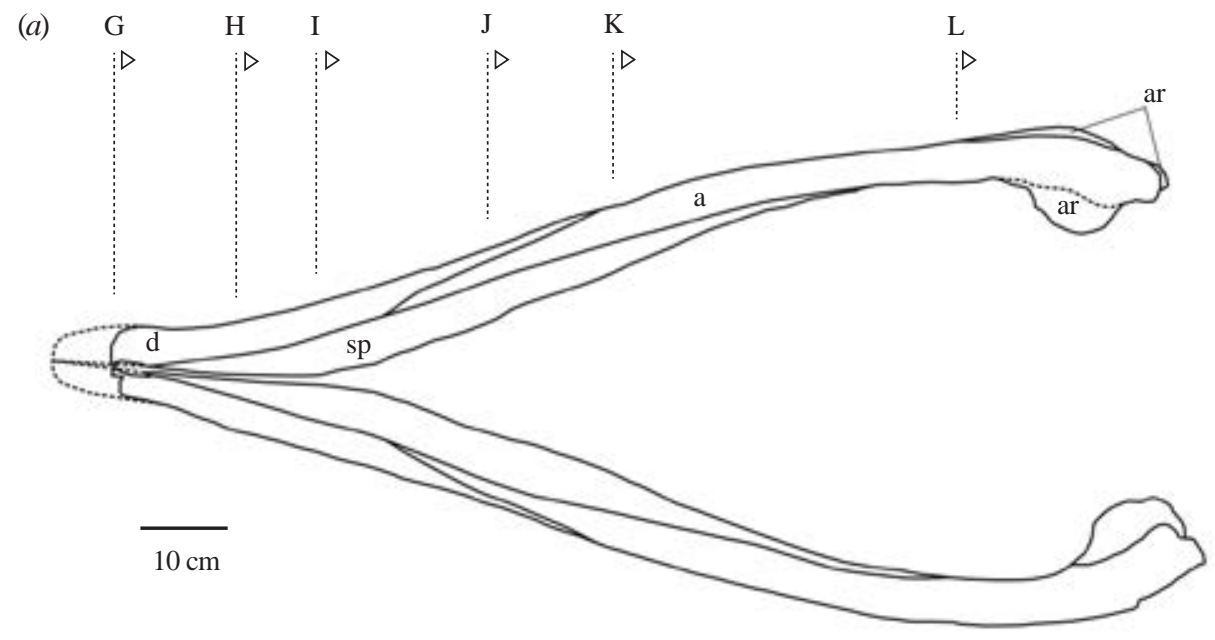

(b)

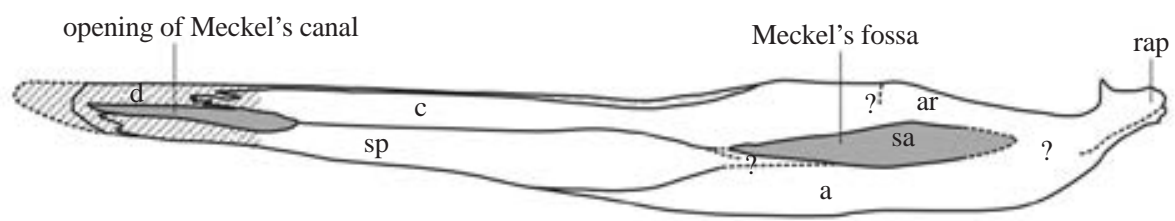

(c)

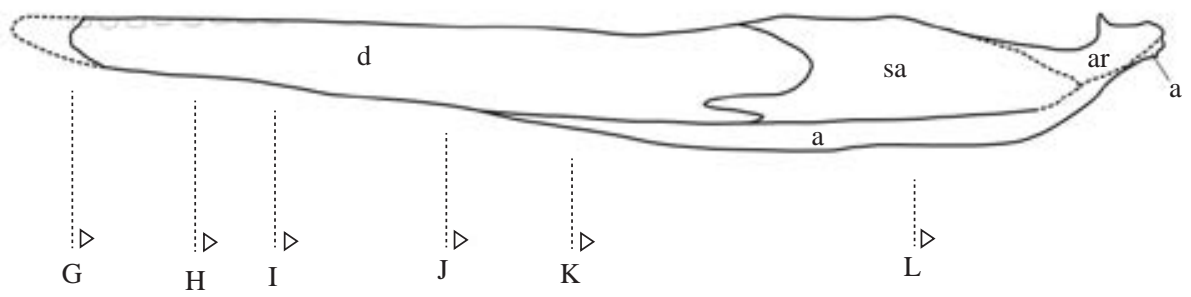

(d)
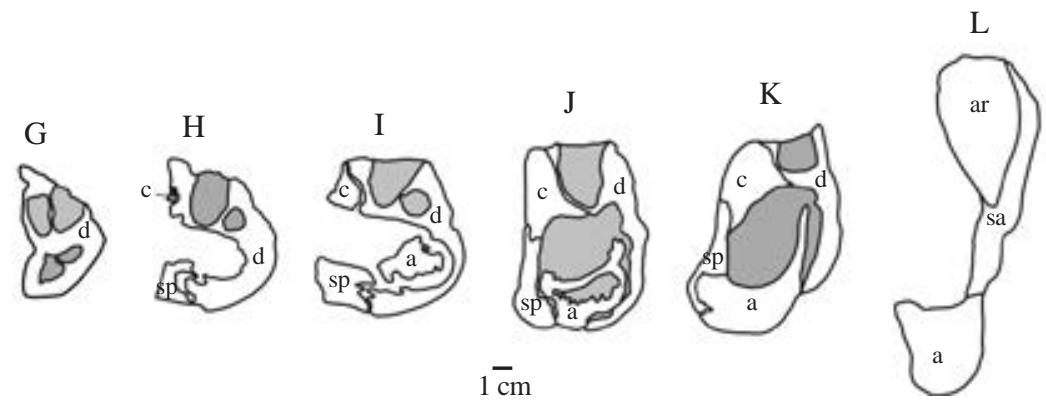

Figure 6. VL17052004-1, holotype specimen of Stenorhynchosaurus munozi gen. and sp. nov. Mandible. $a$ : in ventral view. $b$ : in medial view of the right ramus. $c$ : lateral view of the left ramus. $d$ : cross sections of the right ramus indicated in $a, c$ and Figure 3 , looking from anterior view. Abbreviations: a, angular; ar, articular; d, dentary; c, coronoid; rap, retroarticular process; sa, surangular; sp, splenial.

The distribution of bones along the mandible, both internally and externally, is revealed by breaks occurring along the length of the mandible (Figure $6 \mathrm{~d}$ ). These cross-sections illustrate the dentary forming the whole of the symphysial area anteriorly, and the majority of the lateral surface of the mandible anterior of the coronoid eminence. Medially the splenial forms the floor of the mandibular symphysis posteriorly, and extends posteriorly to the opening of Meckel's canal, ventral to, and contacting the coronoid. Posteriorly, the angular forms progressively more of the mandibular ramus ventrally, contacting the surangular laterally, and forming the floor of Meckel's canal dorsally (Figure 6 b). Laterally, just anterior of the coronoid process, the dentary joins the surangular posteriorly in a sinusoidal suture. The angular forms more than half of the ventral surface of the mandible posteriorly (Figure 6). The short and dorsally inclined retroarticular process is formed by the articular and angular, but the sutures are not entirely clear. The dorsal surface of the retroarticular process, for attachment of the jaw opening muscles, is rugose. 
Teeth and dentition (Figure 5S). The preserved functional teeth are all broken but show a sub-circular cross-section at the level of the base ('root'). Both the maxillary and mandibular teeth diminish in size posteriorly, the anterior teeth measuring 20 to $25 \mathrm{~mm}$ in diameter, those at the posterior of the jaw somewhat smaller in diameter. In the premaxilla none of the teeth is completely preserved, however, the posterior tooth in the left premaxilla exhibits a small part of the base and the lowermost part the crown with enamel ridges; the surface of the base is smooth. The maxillae preserve few teeth in situ. In the right maxilla, the seventh functional alveolus contains a nearly complete tooth, lacking only its tip. This tooth has a high base, and marked longitudinal ridges concentrated on the lower part of the enamelled crown. A single, poorly-preserved but unbroken mandibular tooth lies on the dental row at the middle (anteroposteriorly) region of the right mandibular ramus horizontally displaced from its original position. This tooth is slender, $45 \mathrm{~mm}$ in length including base and crown, and has a circular cross-section. The crowns of replacement teeth can be seen in the more anterior mandibular and maxillary alveoli (Figure 5S). These tooth crowns are nearly conical having a flat anterior face limited by two slight longitudinal carinae (Figure 5S), one anterolateral the other anteromedial. An additional posterior longitudinal ridge appears toward the apex of the crown forming a trihedral tip of the tooth. The surface of the crown is ornamented with enamel ridges at the base, but smoother at the tip.

An incomplete count of three functional alveoli is preserved in the right premaxilla. The anteriormost functional alveolus preserves an original gentle anterior orientation, suggesting that each premaxilla may not have supported more than four teeth, although the total number of premaxillary teeth remains uncertain. The penultimate preserved functional alveolus, is slightly larger than the other two preserved alveoli. Each maxilla preserves at least 29 functional alveoli, with the fourth maxillary functional alveoli slightly larger. However, this fourth functional alveolus is not sufficiently large to be considered heterodont, so the tooth row can be classed as homodont in character, with slight variation in tooth size along the maxilla. The second functional alveolus is inclined anterolaterally.

In agreement with the form of the rostrum, the mandible exhibits neither lateral expansion nor marked increase in size of the functional alveoli in the anterior of the mandible. At least 10 pairs of functional alveoli are estimated to have lain adjacent to the mandibular symphysis, three anterior to a slight lateral constriction in the mandible (Figure 5S). These functional alveoli are 20 to $25 \mathrm{~mm}$ in diameter and are all inclined slightly anterolaterally. There are 28 functional alveoli preserved in the right dentary, although there were probably a total of 32 to 34 teeth in each mandibular ramus according to the missing part of the jaw, previously discussed. Based on the slight lateral inclination of the functional alveoli, the mandibular teeth would have protruded laterally sufficiently for the tips of the tooth crowns to have passed the lateral margins of the maxillae in life.

Axial skeleton (Figures 1 and 7). The atlas-axis complex is not visible, and the first clear vertebral centrum is wellseparated from the basioccipital condyle. The general form of the cervical vertebrae is similar along the neck, except for the positions of the costal facets which rise slightly dorsally up the lateral surface of the more posterior centra. There are thirteen articulated cervical vertebra preserved as three units; all slightly deformed by compression. The third to fifth vertebral centra as preserved lie perpendicular to the neck, with their long axes transverse to the neck suggesting that the neck was broken (Figure 7 a). Two other cervical centra were recovered, one on the left of the post-occipital region and the other inside the right temporal fenestra. Based on the articulated elements and the two isolated vertebrae, the neck of Stenorhynchosaurus must have contained at least seventeen cervical vertebrae, including the missing atlas-axis.

Due to lack of preservation, the cervical vertebrae lack their neural arches. The articular facets are slightly concave and wider than high; the cervical vertebrae are also wider than long (Table 2). The second cervical centrum in the first articulated series preserves the right cervical rib articulated, whilst the seventh, and ninth to twelfth centra preserve their left cervical ribs disarticulated and slightly displaced from their original positions. The cervical ribs are dorsoventrally compressed; distally shorter than proximally; the posterior ones as long as the width of centra, and longer than anterior. The external surfaces of the cervical centra are smooth and show on each lateral surface as a single, trough-like costal facet extending almost the entire length of the vertebral body (Figure $7 \mathrm{~b}$ ). The ventral surfaces of the cervical centra exhibit a poorly-defined, low ventral ridge on the anterior of the vertebral body without an anterior lip.

Twenty-three articulated post-cervical vertebrae are preserved. A further five post-cervical vertebrae were found separated from the posterior of the skeleton. The postcervical vertebrae all have disarticulated neural arches suggesting that they were not originally fused to the centra. It is not possible to differentiate the pectoral series. The dorsal centra are not well preserved and are rotated to the left side. The anterior dorsal vertebrae have neural arches and spines lying to the right of the vertebral column whereas the posterior dorsal vertebrae have their neural arches reclined toward the left as a result of the disarticulation and compression of the carcass (Figure 1). The neural spines of the dorsal vertebrae are high laterally compressed, with the anterior border slightly convex and the posterior slightly concave. The dorsal ribs are slender, and separated from the articular facets of the vertebrae with which they articulated. The dimensions of some vertebral centra are given in Table 2. 


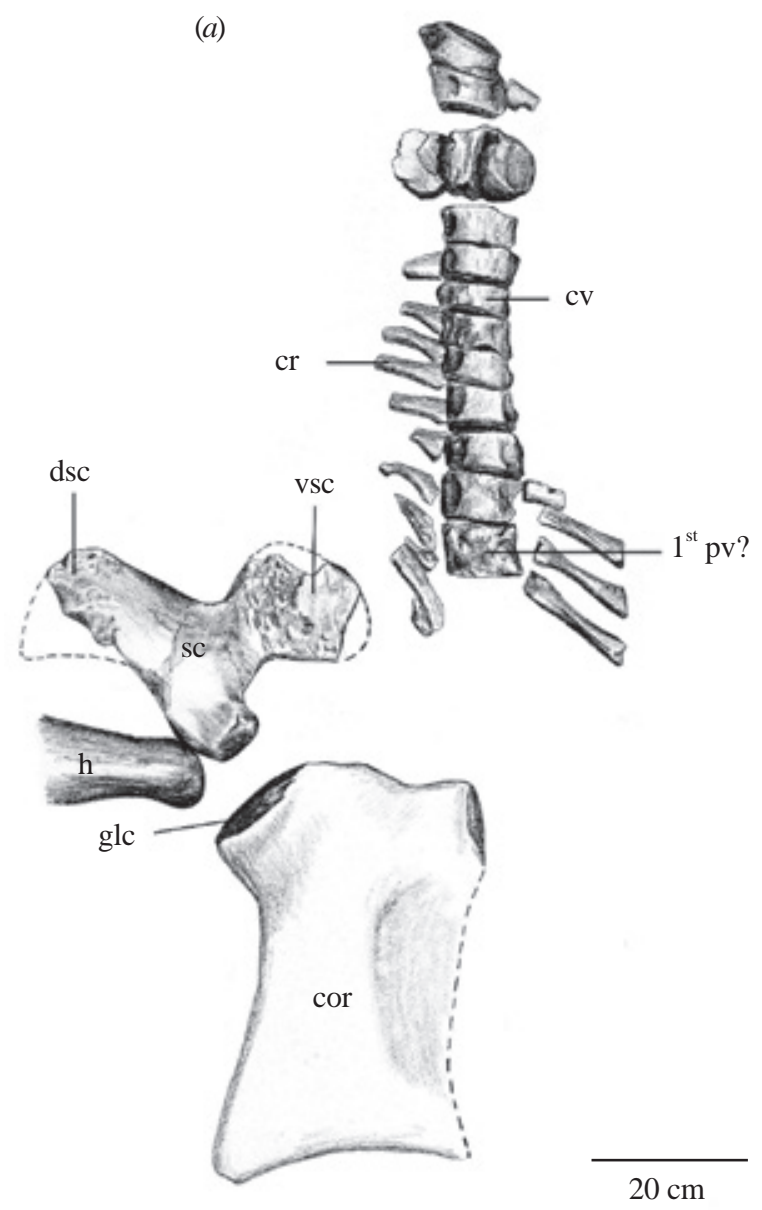

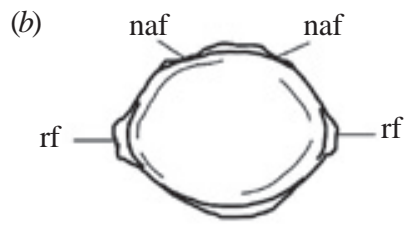
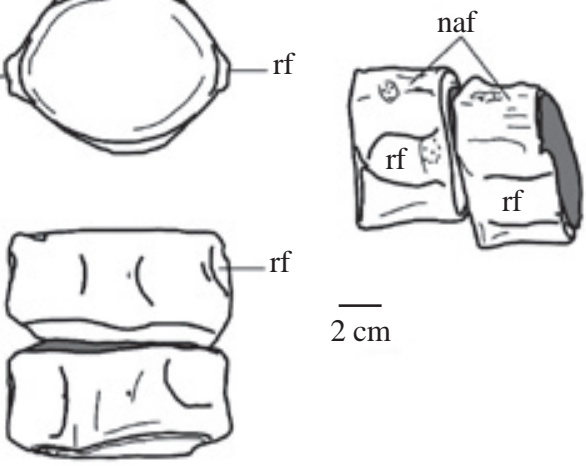

$\overline{2 \mathrm{~cm}}$

(d)
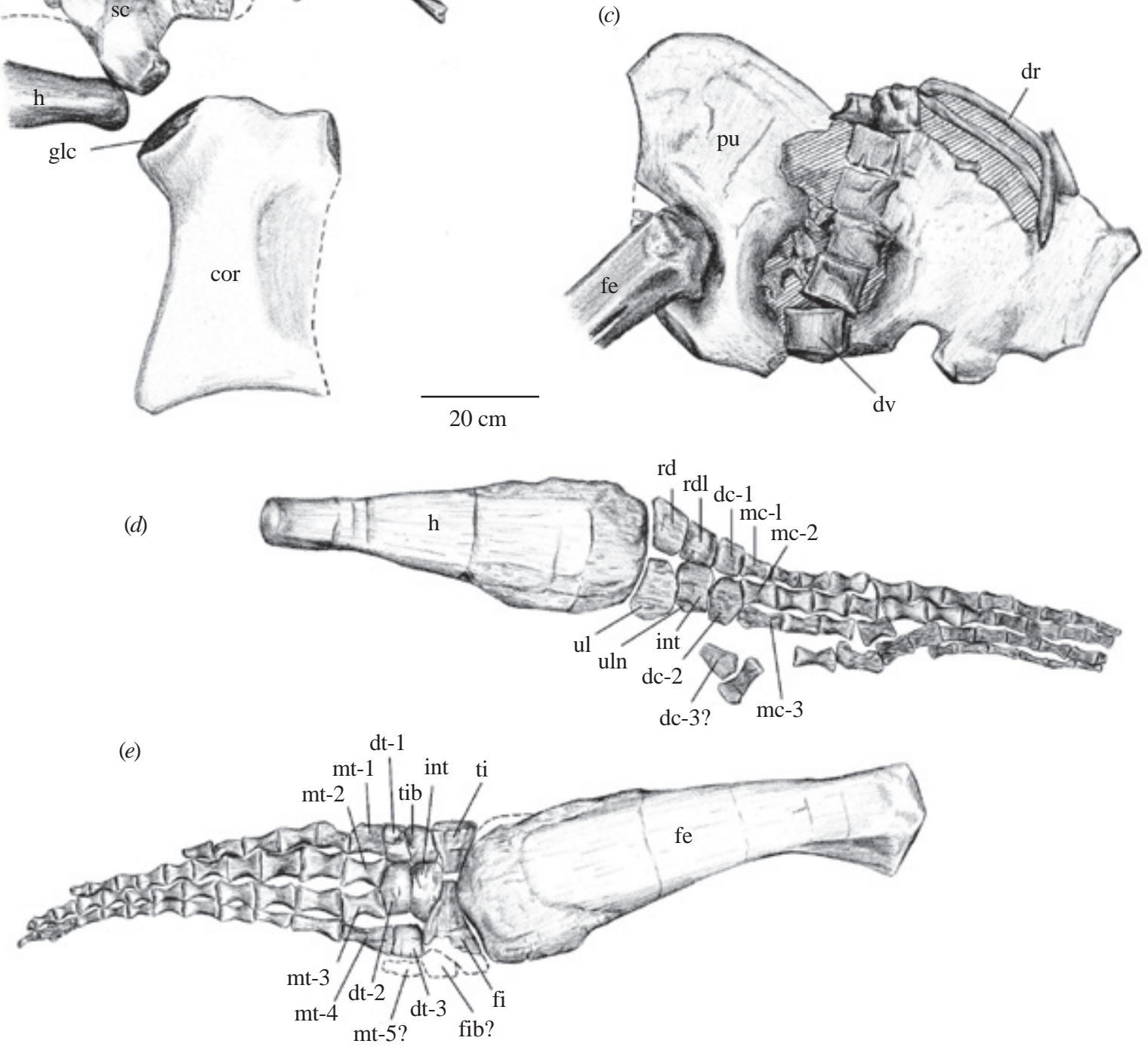

Figure 7. VL17052004-1, holotype specimen of Stenorhynchosaurus munozi gen. and sp. nov. Post-cranial elements, $a$ : neck and left scapula and coracoids in dorsal view. $b$ : $8^{\text {th }}$ and $9^{\text {th }}$ cervical vertebrae in posterior (top), left lateral (right) an ventral views (bottom). $c$ : pelvic region in dorsal view. $d$ : right fore-limb in dorsal view. $e$ : left hind limb in dorsal view. Abbreviations: cor, coracoid; cr, cervical rib; cv, cervical vertebra; dc-1 to 3, distal carpals; dr, dorsal rib; dsc, dorsal process of scapula; dt-1and 2, distal tarsals; dv, dorsal vertebra; fe, femur; fi, fibula; fib, fibulare; glc, glenoid cavity; h, humerus; int, intermedium; mc-1 to 3, metacarpals; mt-1 to 4, metatarsals; naf, facet for neural arch; pu, pubis; pv, pectoral vertebra; rd, radius; rdl, radiale; rf, facet for rib; sc, scapula; ti, tibia; tib, tibiale; ul, ulna; uln, ulnare; vsc, ventral process of scapula. 
Limb girdles (Figures 7 a and c). The pectoral and pelvic girdles are incompletely preserved and can only be observed in dorsal view, so much detail is obscured by the axial elements. From the pectoral girdle the left scapula and coracoid are the most complete. At the glenoid the bones are greatly separated indicating that they are not preserved in their original positions. The scapula is a triradiate bone with all surfaces preserved in a single plane. The scapula has a very well-developed dorsal process anterolaterally. Its ventral plate is relatively robust and does not join its counterpart on the right as preserved. The coracoid is a large, sub-rectangular bone, exhibiting the anterolateral glenoid cavity, a medial facet anteromedially for median symphysis with the right coracoid, and a slight somewhat rounded and pointed 'corner' posterolaterally representing the poorly developed posterolateral cornua. No anteromedial process appears to be present. The articular facets for the humerus and scapula are not clearly differentiated, with a single large, rounded articulating facet present, which suggests a juvenile ontogenetic stage for Stenorhynchosaurus

From the pelvic girdle, only the pubes are preserved substantially complete. The left pubis is the most complete but the midline union and its attachment to the ischium are not visible. The left pubis is in general relatively thick. Its medial border is covered by the vertebral column but its anterior border is convex anteriorly. The right pubis is fractured and displaced from its original position. The anterior border is damaged and the bone gently rotated clockwise, resulting in the acetabular facet lying under the vertebrae which are displaced to the left.

Appendicular skeleton (Figures $7 \mathrm{~d}$ and e). All limbs are somewhat incomplete with the forelimb smaller than the hindlimb. The left forelimb lacks the distal end of the humerus and the majority of the phalanges; the right fore-limb and the left hindlimb preserve only four digits limb; and the right hindlimb preserves just a few disarticulated fragments.

The humerus and femur are relatively long and narrow (Figure $7 \mathrm{~d}$ ). The distal expansion of the humerus is weaklydeveloped, just a little wider than the shaft. The anterior border of the femur (Figure 7 e) is very slightly convex and the posterior border is slightly concave. The proximal articulations of the propodials show relatively continuous surfaces without differentiated capitulum and tuberosity; the trochanter is also undifferentiated. In both the humerus and femur, the distal epiphyses are poorly ossified and show rounded edges without marked articular surfaces for the epipodial elements. These rounded articulating surfaces once again suggest a juvenile ontogenetic stage.

The epipodials in both the fore- and hindlimbs are extremely short, as is typical for Cretaceous plesiosaur genera (Brown, 1981). The epipodials exhibit a clear separation between the two elements (Figures $7 \mathrm{~d}$ and e). The radius is smaller than the ulna, with approximately straight borders. The proximal surface of the radius is flat for union with the humerus; the postaxial border is short and perpendicular to the proximal border, and the preaxial border is longer and inclined posterolaterally. Distally the radius bears a long facet at right angles to its longitudinal axis for union with the radiale, and a very short posterolaterally inclined facet for the intermedium. The ulna is wider than long; the preaxial border is short whereas the postaxial border is broken. Distally the ulna exhibits two inclined facets, one angled anterolaterally for the intermedium and a second for the ulnare. A third posterolaterally inclined facet was also present. Three proximal carpals are preserved, although the ulnare is incomplete. In the right forelimb only digits I to IV are preserved with the majority of the bones of the paddle slightly displaced posteriorly (Figure $7 \mathrm{~d}$ ). Some of the phalanges of the fourth digit of the right forelimb are disarticulated, with a quadrangular bone (probably distal carpal 3) and several phalanges separated from the paddle. The first digit is the most complete preserving twelve phalanges, however, the distalmost phalanges are not preserved. In the left anterior paddle (Figure 1) only a section of the paddle with five phalanges is preserved indicating five digits were originally present.

Only the left hindlimb is preserved (Figure 7 e). The fibula is larger than the tibia, although both bones have a subtriangular shape with very short inner ('deep') borders and much larger outer (anterior or posterior) borders; the facets for the proximal tarsals are not clearly marked. A quadrangular tibiale and a short but larger intermedium are present, although the fibula is not preserved. Three distal tarsal elements are present and show the usual shape in pliosaurids (Andrews, 1913; Welles, 1962). The greatest number of phalanges is preserved in the third digit, where twelve are present. As with the right forelimb, only four digits are preserved in the left hindlimb, although this is presumably a result of incomplete preservation.

\section{Systematic discussion}

Remains of Lower Cretaceous pliosaurids are scarce globally. In Colombia, one pliosauromorph taxon of a similar age to Stenorhynchosaurus munozi (Barremian) is known from the Hauterivian-Albian age Paja Formation close to Villa de Leiva: the Albian (Upper Cretaceous) Kronosaurus boyacencis Hampe,1992 from Vereda Monquirá (Figure 1S). Other new taxa await formal description. Kronosaurus Longman 1924 was originally described from the Great Artesian Basin, Australia, where various AptianAlbian specimens referred to Kronosaurus queenslandicus Longman 1924 have been described (Longman, 1932; White 1935; Romer \& Lewis, 1959), including MCZ 1284 and QMF 51291 (McHenry, 2009). However, Stenorhynchosaurus, previously referred to Brachauchenius sp. (Hampe, 2005), is an important specimen, not only because it was recovered from the Lower Cretaceous, but 
also because of the scarcity of Barremian pliosauromorph material generally. The substantially complete skeleton of Stenorhynchosaurus, preserving both skull and postcranial material, allows comparison of many phylogenetically important characters to previously described pliosauromorph taxa.

\section{Phylogenetic context}

Stenorhynchosaurus munozi is a pliosaurid plesiosaur as traditionally defined (e.g. Tarlo, 1960, Brown, 1981), preserving a large skull and a short neck. Stenorhynchosaurus superficially shares affinities with the Brachaucheninae Benson and Druckenmiller, 2014, preserving a long, relatively straight-sided snout with homodont dentition (Hampe, 2005; this work). In addition, the Brachaucheninae are the only group of pliosaurids known from the Lower Cretaceous (Benson and Druckenmiller, 2014). However, in the absence of a full cladistic investigation of the Colombian pliosaurids (outside the scope of this contribution), we evaluate the possible phylogenetic position of Stenorhynchosaurus by comparison to the diagnostic characteristics (summarized in Table 3) proposed in the most recent phylogenetic analyses (Ketchum and Benson, 2010; Benson, et al., 2013; Benson and Druckenmiller, 2014). Hence below, we compare Stenorhynchosaurus to the ever more inclusive clades Pliosauroidea Welles, 1943; Pliosauridae Seeley, 1874 (both sensu Ketchum and Benson, 2010); Thalassophonea Benson and Druckenmiller 2014; and the two derived groups within Thalassophonea, the Jurassic Pliosaurus (Benson, et al., 2013), and the Cretaceous sub-family Brachaucheninae Benson \& Druckenmiller, 2014.

Of the synapomorphies proposed as diagnostic of the five clades (Pliosauroidea, Pliosauridae, Thalassophonea, Pliosaurus, and Brachaucheninae), a sub-set can be compared with Stenorhyncosaurus: those preserved in the new genus, and either shared or not shared with the groups above (highlighted in bold and italics respectively in Table $3)$. The remaining characters are either not applicable due to the nature of the analyses (the 'bins' used for continuously variable characters (Ketchum \& Benson, 2010) depend on the addition or removal of taxa, and so are not comparable between analyses; see Benson \& Druckenmiller, 2014: 5 ), or are not preserved in the new genus; these later characters are not discussed further. As diagnostic characters (synapomorphies) are derived from the cladistic analyses cited, characters and character states are shown as numbers in square brackets thus: [10.1], where the first number is the character, separated by a full stop from a second number that represents the character state; full descriptions of the characters and character states can be found in the works cited.

\section{Pliosauroidea and Pliosauridae}

Stenorhynchosaurus munozi shares four of 11 diagnostic characters with Pliosauroidea (Table 3). The palate of
Stenorhynchosaurus, posterior of the anterior interpterygoid vacuity is bordered by the pterygoid [60.0] as in Peloneustes philarchus (Andrews, 1913, Ketchum and Benson, 2011a), and the pterygoids form a midline suture posterior to the posterior interpteryoid vacuity [63.1] as in Maresaurus coccai (Gasparini, 1997). In the mandible the angular and prearticular form a rounded medial flange anterior to the glenoid fossa in dorsal view [102.0] as in Peloneustes (Andrews, 1913, Ketchum and Benson, 2010). The diastema at the premaxilla-maxilla suture [48.1] is present as in Peloneustes philarchus (Andrews, 1913, Ketchum and Benson, 2011a).

Stenorhynchosaurus shares eight of 28 diagnostic characters with Pliosauridae, with three characters not shared (Table 3). In the skull roof, Stenorhynchosaurus shares with Pliosauridae the premaxilla separated from the margin of the external naris [8.1] as in Liopleurodon ferox (Andrews, 1913, Noè, 2001), and on the palate the pterygoid forms a flange lateral and posterior to the posterior interpterygoid vacuities [64.1] as in Kronosaurus queenslandicus (McHenry, 2009). In the mandible Stenorhynchosaurus shares a coronoid with a long lingual process [90.1] as in 'Pliosaurus' andrewsi (Tarlo, 1960), and a weakly developed longitudinal medial crest ventral to the coronoid eminence and just ventral and anterior of the entrance to Meckel's canal [97.1] as in Simolestes vorax (Ketchum \& Benson, 2010). The cervical centra in Stenorhynchosaurus exhibit a flat or only slightly convex ventral surface [123.0] as in Brauchauchenius lucasi (Albright, et al., 2007), and a gently convex articular face [124.1] as in Marmornectes candrewi (Ketchum \& Benson, 2011b). In the postcranial skeleton, Stenorhynchosaurus shares the absence of postaxial ossicles in the epipodial row of the forelimb [161.0] as in Peloneustes philarchus (Ketchum \& Benson, 2011a), and a radius with a pre-axial margin straight or slightly convex [163.1] as in Liopleurodon ferox (Andrews, 1913). All diagnostic characters of Pliosauridae not shared by Stenorhynchosaurus are postcranial, with the pre-glenoid extension of the coracoid relatively wide in Stenorhynchosaurus, but narrow in Pliosauridae [150.1], the preaxial margin of the humerus straight in Stenorhynchosaurus rather than concave in dorsal or ventral view in pliosaurids [157.1], and the convex pre-axial surface of the tibia in Pliosauridae [178.1] not present in Stenorhynchosaurus (Ketchum \& Benson, 2010; this work). On balance, the evidence appears to suggest Stenorhynchosaurus is a member of Pliosauroidea, and most probably of Pliosauridae (with less character congruence and hence less certainly), although some characters contrary to this inference.

\section{Thalassophonea}

Comparison of Stenorhynchosaurus with Thalassophonea Benson \& Druckenmiller, 2014, which is predominantly diagnosed on postcranial characteristics (Table 3), is more problematic. Stenorhynchosaurus shares just one 
Table 3. Summary of diagnostic cladistic characters for clades Pliosauroidea, Pliosauridae, Thalassophonea, genus Pliosaurus, and the sub-family Brachaucheninae abstracted from recent phylogenetic analyses, and organized by region of the body, highlighting characters shared (S, in bold), not shared (NS, in italics) together with those not preserved (NP) and not applicable (NA) to Stenorhynchosaurus munozi gen. et sp. nov.

\begin{tabular}{|c|c|c|c|c|c|}
\hline & Pliosauroidea & Pliosauridae & Thalassophonea & Pliosaurus & Brachaucheninae \\
\hline \multirow{9}{*}{ Cranium } & 3.H, NA & 1.8, NA & 54.1, NP & 24.1, $S$ & $1.0, \mathrm{~S}$ \\
\hline & 10.2, NP & 2.L, NA & & 40.1, NP & 4.2, $\mathrm{S}$ \\
\hline & & 8.1, S & & 63.2, NP & 13.0, $\mathrm{S}$ \\
\hline & & 14.0, NP & & & $29.2, \mathrm{~S}$ \\
\hline & & 33.1, NP & & & 31.0, NS \\
\hline & & 34.1, NP & & & $35.1, N S$ \\
\hline & & 37.1, NP & & & 42.1, NP \\
\hline & & & & & 54.0, NP \\
\hline & & & & & 57.1, NP \\
\hline \multirow{4}{*}{ Palate } & 48.1, $S$ & 55.1, NP & & & 84.1, NP \\
\hline & $60.0, S$ & 64.1, $S$ & & & 86.0, $S$ \\
\hline & 63.1, $\mathrm{S}$ & & & & \\
\hline & 74.2, NP & & & & \\
\hline \multirow{3}{*}{ Mandible } & 102.0, S & 90.1, S & 114.1, NP & 127.3, NP & $10.1, \mathrm{~S}$ \\
\hline & & 95.H, NA & & & 113.0, NP \\
\hline & & 97.1, S & & & 123.1, S \\
\hline \multirow{2}{*}{ Teeth } & & 111.D, NA & 132.1, NS & $139.1, .2, \mathrm{~S}$ & 132.0, NP \\
\hline & & 112.A, 112.G, NA & & 140.1, NP & 133.0, S \\
\hline \multirow{4}{*}{ Vertebrae } & 118.B, NA & 118.7, NA & 142.1, NP & & 156.2, S \\
\hline & & 123.0, S & & & 162.1, NP \\
\hline & & 124.1, S & & & 163.1, NP \\
\hline & & & & & 181.0, NP \\
\hline \multirow{12}{*}{ Appendicular } & 144.1, NP & 143.0, NP & 216.1, S & 256.1, S & \\
\hline & 154.9, NA & 150.1, NS & 224.3, NP & 259.1, S & \\
\hline & 177.B, NA & 153.6, NA & 238.1, NS & & \\
\hline & & 155.C, NA & 244.2, NS & & \\
\hline & & 157.1, NS & 245.1, NS & & \\
\hline & & 161.0, S & 251.2, NS & & \\
\hline & & $162.5,162.8, \mathrm{NA}$ & & & \\
\hline & & 163.1, S & & & \\
\hline & & 168.2, NP & & & \\
\hline & & 173.J, NA & & & \\
\hline & & 177.7, NA & & & \\
\hline & & 178.1, NS & & & \\
\hline
\end{tabular}

Source of characters: Pliosauroidea and Pliosauridae Ketchum \& Benson (2010); Thalassophonea and Brachaucheninae Benson \& Druckenmiller (2013); and Pliosaurus Benson et al. (2014).

diagnostic synapomorphy with Thalassophonea, however, five diagnostic characters are not shared, out of a total of ten diagnostic characters proposed for the sub-family (Benson \& Druckenmiller, 2014). The character shared between Thalassophonea and Stenorhynchosaurus is an absence on the coracoid of a low, mediolaterally oriented buttress connecting the glenoid to the median symphysis on the ventral surface [216.1] as in Peloneustes philarchus (Andrews, 1913, Ketchum \& Benson, 2011a) and Liopleurodon ferox (Andrews, 1913, Noè, 2001) but otherwise unknown in the taxa analysed by Benson \& Druckenmiller (2014). However, Stenorhynchosaurus does not share the reduced distal-most alveolus in the posterior of the premaxilla [132.1] seen in a range of taxa 
including 'Pliosaurus' andrewsi, Liopleurodon ferox and Pliosaurus brachyspondylus (Tarlo, 1960), but not present in Megacephalosaurus eulerti (Schumacher, et al., 2013) or Brachauchenius lucasi Williston, S.W. 1903 (Albright, et al., 2007). In addition, Stenorhynchosaurus does not share with Thalassophonea propodials with a weakly concave region that separates a central, convex portion from strongly tapering, flange-like pre- and post-axial margins [238.1] seen in Peloneustes philarcus, Simolestes vorax and Liopleurodon ferox, but reversed in Pliosaurus and Brachaucheninae (Benson and Druckenmiller, 2014). The remaining three characters not shared between Thalassophonea and Stenorhynchosaurus are a humerus length width ratio of 1.7-2.2 (2.94 in Stenorhynchosaurus) [244.2] as in Peloneustes philarcus, Simolestes vorax and Liopleurodon ferox; a concave preaxial margin of the distal humerus in dorsal or ventral view, but with the anterior expansion relatively small, and substantially less than posterior expansion [245.1] seen in Peloneustes philarcus, Simolestes vorax and Liopleurodon ferox (as the distal humerus expands anteriorly in Stenorhynchosaurus); and a femoral length:width ratio of 1.55-2.0 [3.25 in Stenorhynchosaurus) [251.2] as in Peloneustes philarcus and Simolestes vorax (Benson and Druckenmiller, 2014: data matrix). However, none of these latter three characters are known in any of the Brachaucheninae taxa analysed (Benson and Druckenmiller, 2014). Hence placement of Stenorhynchosaurus within the Thalassophonea is extremely problematic. However, congruence of characters with members of Pliosaurus and Brachaucheninae (below) suggests Stenorhynchosaurus can be referred to one of the advanced members of the Thalassophonea, rather than being excluded and possibly requiring erection of a new supra-genus level taxonomic group within Pliosauroidea-Pliosauridae.

\section{Pliosaurus}

Stenorhynchosaurus shares half (four out of eight) of the diagnostic characters of Pliosaurus, with no diagnostic characters not shared ((Table 3). One character Stenorhynchosaurus shares with members of Pliosaurus is the presence of sub-trihedral teeth [139.2], as observed in Pliosaurus kevani Benson, et al., 2013 and the Cuban Gallarodsaurus iturraldei Gasparini, 2009. Trihedral [139.1] (or sub-trihedral) teeth were long seen as the defining character of Pliosaurus (e.g. Owen, 1841), or the Kimmeridgian pliosaurs [sic] (Tarlo, 1959; Tarlo, 1960); the full implications of trihedral teeth in Colombian Cretaceous pliosaurids will be explored elsewhere (Noe \& Gómez in prep.). Other characters shared between Stenorhynchosaurus and Pliosaurus are a premaxillamaxilla suture prominently interdigitating with a 'zigzag' appearance anterolaterally [24.1] as in Pliosaurus kevani, and considered a unique synapomophy of Pliosaurus (Benson, et al. 2013) (although also present in Lioplerodon ferox and Simolestes vorax (Noè, 2001)); and the radius [256.1] and tibia [259.1] with a straight or convex pre-axial margin: convex in Pliosaurus carpenteri, and a referred specimen of Pliosaurus kevani; flat in Pliosaurus brachydeirus and Pliosaurus ? brachyspondylus, but unknown in nine other Pliosaurus specimens studied (Benson, et al., 2013). The proximal surfaces of radius and tibia are only markedly convex in larger individuals of Pliosaurus, indicating this is an ontogenetic feature (Benson, et al., 2013), and the same is inferred to be the case for Stenorhynchosaurus (this work).

\section{Brachaucheninae}

Stenorhynchosaurus shares nine out of 20 diagnostic characters of Brauchaucheninae with two diagnostic characters not shared (Table 3). Brauchaucheninae and Stenorhynchosaurus share four cranial characters: absence of a transverse constriction of the rostrum at the premaxillamaxilla suture [1.0], a relatively long pre-orbital skull length to total skull length ratio ( $>0.56)$ dorsal view [4.2] (at least 0.567 in Stenorhynchosaurus); the alveolar margin of upper jaw approximately straight in lateral view [13.0]; and a maxilla that extends posteromedial to the external naris [29.2], all as in Megacephalosaurus eulerti and Brachauchenius lucasi (Benson \& Druckenmiller, 2014). One character of the palate is shared between Brauchaucheninae and Stenorhynchosaurus, the anteroventral surface of the parasphenoid ventrally covered by the pterygoids anterior to the posterior interpterygoid vacuity [86.0], as seen in Kronosaurus queenslandicus, Megacephalosaurus eulerti and Brachauchenius lucasi (Albright, et al., 2007; McHenry, 2009; Schumacher, et al., 2013). Two characters of the mandible, the mandibular glenoid fossa lying just posterior to the occipital condyle [10.1] as in Megacephalosaurus eulerti and Brachauchenius lucasi (although not shared with Kronosaurus queenslandicus MCZ 1284); and a retroarticular process inflected slightly posteromedially [123.1] as in Kronosaurus queenslandicus (MCZ 1284), Megacephalosaurus eulerti and Brachauchenius lucasi (Benson \& Druckenmiller, 2014, and references therein), are shared, together with homodont and dentition [133.0], as in Megacephalosaurus eulerti (Schumacher, et al., 2013) and Brachauchenius lucasi (Williston, 1907). One cervical vertebral character, dorsal foramina present within the neural canal, but subcentral foramina very small or absent [156.2], as in Brachauchenius lucasi (Albright, et al., 2007), is also shared with Stenorhynchosaurus. Two skull roof characters are not shared by between Brauchaucheninae and Stenorhynchosaurus: the frontal does not participate in the rim of the external nares [31.0] in Stenorhynchosaurus, and the prefrontal does not participate in the rim of the external naris [35.1], both of which are present in Megacephalosaurus eulerti, Brachauchenius lucasi and Kronosaurus queenslandicus (QM 51291) (Williston, 1907; McHenry, 2009; Schumacher, et al., 2013). Hence 
the balance of evidence indicates that Stenorhynchosaurus could be placed within the Brauchaucheninae, although not unambiguously.

Summarizing the foregoing, referral of Stenorhynchosaurus to Pliosauroidea and Pliosauridae, although not entirely supported by the available evidence, nonetheless seems likely. As currently defined, firm inference of referral of Stenorhynchosaurus to Thalassophonea is much more problematic, but ultimately seems highly likely based on characters shared with Pliosaurus and Brachaucheninae; however, this uncertainty indicates Thalassophonea requires rigorous redefinition. As to whether Stenorhynchosaurus is a member of the currently exclusively Jurassic Pliosaurus, or the Cretaceous Brachaucheninae, appears equivocal. However, referral Stenorhynchosaurus to both Pliosaurus and Brachaucheninae is not possible as the two clades are mutually exclusive, based on current phylogenetic hypotheses (Ketchum \& Benson, 2010; Benson, et al., 2013; Benson \& Druckenmiller, 2014). This leaves four possible hypotheses: (i) Stenorhynchosaurus belongs within Pliosauroidea and Pliosauridae but outside Thalassophonea, (ii) Stenorhynchosaurus is a member of Thalassophonea but separate from either Pliosaurus or Brachaucheninae, (iii) Stenorhynchosaurus resides within Pliosaurus, or (iv) Stenorhynchosaurus is a member of subfamily Brachaucheninae. However, all four possibilities represent problems for current phylogentic hypotheses of Pliosauroidea.

Hypothesis (i) would place Stenorhynchosaurus close to Thalassiodracon hawkinsi, Haufiosaurus, Attenborousaurus conybeari and Marmonectes candrewi at the base of the Pliosauridae (Benson, et al., 2013, Benson \& Drukenmiller, 2014), which seems highly unlikely for a Cretaceous taxon. Hypothesis (ii) would indicate the need for considerable redefinition of Thalassophonea, and both hypotheses (i) and (ii) would imply (a) a ghost lineage within Pliosauroidea into the Lower Cretaceous, and (b) that a second lineage of pliosaurids crossed into the Cretaceous in addition to the Brauchaucheninae. Hypothesis (iii) would extend the temporal range of Pliosaurus from the Late Jurassic into the Lower Cretaceous, greatly increase morphological variability, as well as indicating two lines of pliosaurids crossed into the Cretaceous. This possibility would therefore indicate the need for a major revision of Pliosaurus, most likely including multiple genera (as previously suggested by Noè, et al., 2004). Hypothesis (iv) would require redefinition of Brachaucheninae to incorporate Stenorhynchosaurus. All hypotheses will be rigorously tested in future contributions following publication of specimens awaiting formal description. Hence Stenorhynchosaurus underlines the need for continuing exploration of the systematics of Pliosauridae and reinforces the need to eliminate remaining instability within the evolutionary tree of Plesiosauria.

\section{Conclusions}

The characteristics of Stenorhynchosaurus munozi, a new Lower Cretaceous pliosaurid from the Barremian Arcillolitas Abigarradas Member of the Paja Formation of Colombia, are sufficiently different from known taxa to permit erection of a new genus and species. Stenorhynchosaurus is characterized by the anterior of the vomer, in ventral view, posterior of the palatal premaxillamaxilla suture contacting the posterior palatal process of the premaxilla level with the third maxillary alveolus; rostrum narrow and elongated with straight sides in dorsal view; lacrimal forming the anterior border and great part of the ventral border of the orbit and broadly borders the maxilla anteri-orly; anterior interpterygoid vacuity present; internal nares located between vomer and maxilla at the level of $13^{\text {th }}-15^{\text {th }}$ maxillary alveoli; anterior of rostrum and mandible without lateral expansion or marked increase in size of the functional alveoli; penultimate premaxillary alveolus slightly larger than adjacent premaxillary alveoli; homodont maxillary functional alveoli, with fourth tooth positions very slightly enlarged with respect to the neighboring alveoli; homodont dentary dentition; and epipodials extremely short. Various features of the skeleton, including many clearly visible cranial sutures, an open mandibular symphysis, neural arches unfused to the associated centra, and articular facets on the limb girdles, propodials and radius and tibia rounded and incompletely formed, indicate that the individual was a juvenile (sensu Brown, 1981) at the time of death. Following death, the skeleton apparently remained largely undisturbed by predators, but was slightly affected by early physical biostratinomic (taphonomic) processes which removed elements of the right rear limb and tail.

Based on comparison to recent large-scale cladistic analyses of Plesiosauria (Ketchum \& Benson, 2010; Benson, et al., 2013; Benson \& Druckenmiller, 2014) Stenorhynchosaurus shares a mosaic of characters found within Pliosauroidea, with perhaps with the greatest affinity with the sub-family Brachaucheniinae. However, analysis of diagnostic synapomorphic characters of Pliosauroidea, Pliosauridae, Thalassophonea, Pliosaurus and Brachaucheninae indicates much instability within the phylogeny of Plesiosauria as currently understood. Considerable work thereby remains to be undertaken. Particular problems include definition of Thalassophonea to include new (and existing) specimens, the distribution of characters such as trihedral or sub-trihedral teeth within Pliosaurus (indicating the need for urgent revision), and greater exploration of the details of the evolutionary history of the Thalassophonean sub-family Brachaucheninae. The apparently labile and homoplastic nature of characters employed in existing phylogenetic hypotheses need to be further explored, indicating a particular need to reevaluate relationships with Pliosauroidea, Thalassophonea, and included clades. 
The recognition of Stenorhynchosaurus thereby further underlines the importance of southern continent pliosaurids, and in particular those from the Colombian, Paja Formation. These Lower Cretaceous Colombian pliosauromorphs are likely to prove critical for furthering our understanding of evolutionary relationships within Plesiosauria in general and Pliosauroidea in particular. Stenorhynchosaurus reinforces the importance of Colombian pliosaurids in understanding global interrelationships between plesiosaurian taxa, particularly those within the Lower Cretaceous. The discovery of Stenorhynchosaurus munozi thereby increases the diversity of pliosaurids from the Lower Cretaceous, emphasizes the importance of the marine reptiles from Colombia (and in particular the Villa de Leiva region) as a rich source of morphological and phylogenetic information for understanding the poorly known evolutionary history of Lower Cretaceous Gap pliosaurids.

\section{Información suplementaria}

Figure 1S. Map of Villa de Leiva region with geographical location of the site from which Stenorhynchosaurus muñozi gen. et sp. nov. (VL17052004-1) was recovered (marked by an arrow). A and B indicate the sites of the two other pliosaurids finds: A Kronosaurus boyacensis Hampe, 1992 (Upper Aptian); B - UNDG R1000 (Lower Barremian).

Figure 2S. Generalized stratigraphic column of the Arcillolitas Abigarradas Member of the Paja Formation cropping out around Villa de Leiva, and showing pliosaurid occurrences. A and B indicate the occurrence of the two other pliosaurids finds: A - Kronosaurus boyacensis Hampe, 1992; B - UNDG R1000. Modified from Forero \& Sarmiento, 1985.

Figure 3S. A close-up view of the bed with large rusty calcareous concretions, $60 \mathrm{~cm}$ below the Stenorhynchosaurus muñozi gen. et sp. nov. (VL17052004-1) skeleton, showing an incomplete polygonal pattern interpreted as algal growth cracks developed in a muddy tidal flat. 'Segment C' of the Arcillolitas Abigarradas Member, Paja Formation. View is westward at N5³9’58”, W73³3'59”.

Figure 4S. a, b, c, h, i and j, Gerhardtia galeatoides (Karsten, 1856). a: MP-250604/2a (cf. Pararroyo, 2004, sub Heinzia
(Gerhardtia) galeatoides (Karsten, 1856)); corroded specimen from a calcareous concretion $60 \mathrm{~cm}$ below the skeleton of Stenorhynchosaurus. All specimens in lateral view. b, c: Lateral and ventral views of specimen MP-250604/2c (cf. Patarroyo, 2000, sub Heinzia (Gerhardtia) veleziensis (Hyatt)). h: MP-110804/2 (cf. Patarroyo, 2004, sub Heinzia (Gerhardtia) galeatoides (Karsten)), found inside the skull of Stenorhynchosaurus muñozi gen. et sp. nov. (VL17052004-1). i: MP-171108/1 (cf. Bürgl, 1956, sub Heinzia (Gerhardtia) veleziensis Hyatt); mold of impression of ammonite found inside the skull of Stenorhynchosaurus. j: MP-171108/2 (cf. Patarroyo, 2004, sub Heinzia (Gerhardtia) galeatoides (Karsten, 1856)). d, e, f and g, Gerhardtia provincialis (D’Orbigny, 1850). d: MP-110804/1, small specimen (cf. Vermeulen, 2003), from a calcareous concretion $60 \mathrm{~cm}$ below the skeleton of Stenorhynchosaurus. e: MP-110804/3, ventral view of large specimen in Figure d (cf. Vermeulen 2003). f, g: Lateral and ventral views of specimen MP-250604/2b (cf. Vermeulen, 2003, sub Gerhardtia provincialis (d’Orbigny, 1850)).

Figure 5S. VL17052004-1, holotype specimen of Stenorhynchosaurus munozi gen. and sp. nov. Symphysial region of the mandible in dorsal view and details of replacement teeth.

\section{Acknowledgements}

We thank Mr. Jorge Muñóz for informing us about the find, and facilitating the excavation on his property. We also thank Mary Luz Parra for her significant contribution to the excavation and preparation of the fossil. We thank P. Druckenmiller and two anonymous reviewers for their valuable comments that much improved an earlier draft of this work, and Carlos Jaramillo for editorial advice and help. This study was made possible thanks to the support of the Servicio Geológico Colombiano, the Universidad Nacional de Colombia, the Fundación Colombiana de Geobiología, the local authorities of Villa de Leiva, and Universidad de los Andes, Bogotá.

\section{Conflict of interests}

The authors declare no having any conflict of interest in publishing this article.

\section{Bibliography}

Albright, L.B., Gillette, D.D. \& Titus, A.L. 2007. Plesiosaurs from the Upper Cretaceous (Cenomanian-Turonian) Tropic Shale of Southern Utah, Part 1: new records of the pliosaur Brachauchenius lucasi. Journal of Vertebrate Paleontology 27 (1): 31-40.

Andrews, C.W. 1910. A descriptive catalogue of the marine reptiles of the Oxford Clay: part I. British Museum (Natural History), London, 206 pp.

Andrews, C.W. 1913. A descriptive catalogue of the marine reptiles of the Oxford Clay: part II. British Museum (Natural History), London, 206 pp.

Bardet, N., Mazin, J.M. \& Martin, M. 1993. Une mandibule de Pliosaurus brachyspondylus (Reptilia, Sauropterygia) dans le Kimméridgien du Boulonnais (France). Neues Jahrbuch fuer Geologie und Palaeontologie, Mh. 7: 385-392. 
Benson, R.B.J. \& Druckenmiller, P.S. 2014. Faunal turnover of marine tetrapods during the Jurassic-Cretaceous transition. - Biological Reviews of the Cambridge Philosophical Society 89: 1-23.

Benson, R.B.J., Evans, M., Smith, A.S., Sassoon, J., Moorefaye, S., Ketchum, H.F. \& Forrest, R. 2013. A giant pliosaurid skull from the Late Jurassic of England. - PLoS ONE 8: 1-34.

Blainville, H.D. 1835. Description de quelques espèces de reptiles de la Californie, précédée de l'analyse d'un système général d'Erpétologie et d'Amphibiologie. Nouvelles Annales du Muséum d’Histoire Naturelle, Série 3 (4): 233-296.

Brown, D.S. 1981. The English Upper Jurassic Plesiosauroidea (Reptilia) and a review of the phylogeny and classification of the Plesiosauria. Bulletin of the British Museum of Natural History (Geology) 35 (4): 253-347.

Buchy, M.C., Frey, E. \& Salisbury, S. W. 2006. Internal cranial anatomy of Plesiosauria (Reptilia, Sauropterygia): evidence for a functional secondary palate. Lethaia 39: 290-303.

Bürgl, H. 1956. Catálogo de las amonitas de Colombia, parte 1 Pulchelliidae. Boletín Geológico 4 (1): 1-119.

Cadena, E.A., \& Parham, J.F. 2015. Oldest known marine turtle? A new protostegid from the Lower Cretaceous of Colombia. PaleoBios 32: 1-42.

Carpenter, K. 1997. Comparative cranial anatomy of two North American Cretaceous plesiosaurs. In Callaway, J. M. and Nicholls, E. M. (eds). Ancient Marine Reptiles. Academic Press, San Diego. Chapter 7: 191-216.

Cohen, K.M., Finney, S.C., Gibbard, P.L. \& Fan, J.X. (2013; updated 2015/01). The ICS International Chronostratigraphic Chart. Episodes 36: 199-204.

Cruickshank, A.R.I. 1994. Cranial anatomy of the Lower Jurassic pliosaur Rhomaleosaurus megacephalus (Stutchbury) (Reptilia: Plesiosauria). Philosophical Transactions of the Royal Society of London B 343: 247-260.

Cruickshank, A.R.I., Small, P.G. \& Taylor, M.A. 1991. Dorsal nostrils and hydrodynamically driven underwater olfaction in plesiosaurs. Nature 352: 62-64.

De La Fuente, M., y Goñi, R. 1983. Primeras tortugas cretácicas marinas de Colombia. Geología Norandina 7: 43-48.

D’Orbigny, A. 1841. Paléontologie française, Terrains Crétacés, I, Céphalopodes : 121-456.

D’Orbigny, A. 1850. Note sur quelques nouvelles espèces remarquables d'Ammonites des étages Néocomien et Aptien de France. Journ. Conchyl. I: 196-201.

Etayo Serna, F. 1968. El Sistema Cretáceo en la región de Villa de Leiva y zonas próximas. Geología Colombiana 5: 5-74, 1 mapa.

Forero, H. \& Sarmiento, L.F. 1985. La facies evaporítica de la Formación Paja en la región de Villa de Leiva. Proyecto Cretácico-Contribuciones. Publicaciones Geológicas Especiales del INGEOMINAS. 16: XVII-1-16.

Gasparini, Z. 1997. A new pliosaur from the Bajocian of the Neuquen Basin, Argentina. Palaeontology, 40 (1): 135-148.
Gasparini, Z. 2009. A new Oxfordian pliosaurid (Plesiosauria, Pliosauridae) in the Caribbean seaway. Palaeontology, 52 (3): 661-669.

Goñi, R., y Gasparini, Z. B. 1983. Nuevos restos de 'Alzadasaurus colombiensis' (Reptilia, Plesiosauria) del Cretácico temprano de Colombia. Geología Norandina 7: 49-54.

Hampe, O. 1992. Ein grosswüchsiger Pliosauride (Reptilia: Plesiosauria) aus der Unterkreide (oberes Aptium) von Kolumbien. Courier Forschungsinstitut Senckenberg 145: 1-32.

Hampe, O. 2005. Considerations on a Brachauchenius skeleton (Pliosauroidea) from the lower Paja Formation (late Barremian) of Villa de Leyva area (Colombia). Mitt. Mus. Nat.kd. Berl., Geowiss. Reihe 8: 37-51.

Hyatt, A. 1903. Pseudoceratites of the Cretaceous. United States Geological Survey, Monographs, 44: 128-144.

Karsten, H. 1856. Über die geognostischen verhältnisse des westlischen Columbien, der heutigen Republiken NeuGranada und Equador. Versamm. Deutsch. Natur. Wien, 1856: $80-116$.

Ketchum, H.F \& Benson, R.B.J. 2010. Global interrelationships of Plesiosauria (Reptilia, Sauropterygia) and the pivotal role of taxon sampling in determining the outcome of phylogenetic analyses. Biological Reviews, 85: 361-392.

Ketchum, H.F \& Benson, R.B.J. 2011a. The cranial anatomy and taxonomy of Peloneustes philarchus (Sauropterygia, Pliosauridae) from the Peterborough Member (Callovian, Middle Jurassic) of the United Kingdom. Palaeontology 54 (3): 639-665.

Ketchum, H.F \& Benson, R.B.J. 2011b. A new pliosaurid (Sauropterygia, Plesiosauria) from the Oxford Clay Formation (Middle Jurassic, Callovian) of England; evidence for a gracile, longirostrine grade of Early-Middle Jurassic pliosaurids. Special Papers in Palaeontology 86: 109-129.

Longman, H.A. 1924. A new gigantic marine reptile from the Queensland Cretaceous. Memoirs of the Queensland Museum, 8: 26-28

Longman, H.A. 1932. Restoration of Kronosaurus queenslandicus. Memoirs of the Queensland Museum 10: 98.

McHenry, C.R. 2009. Devourer of gods: the palaeoecology of the Cretaceous pliosaur Kronosaurus queenslandicus. Doctorate, University of Newcastle, Faculty of Science \& Information Technology, School of Environmental and Life Sciences, $\mathrm{x}+616$.

Noè, L.F. 2001. A Taxonomic and Functional Study of the Callovian (Middle Jurassic) Pliosauroidea (Reptilia, Sauropterygia). Unpublished Ph.D. dissertation, University of Derby, Derby. Vol 1:354 pp., Vol 2: 182 pp.

Noè, L.F., Smith, D.T.J. \& Walton, D.I. 2004. A new species of Kimmeridgian pliosaur (Reptilia; Sauropterygia) and its bearing on the nomenclature of Liopleurodon macromerus. - Proceedings of the Geologists’ Association 115: 13-24. 
Owen, R. 1841. Odontography; or a treatise on the comparative anatomy of the teeth; their physiological relations, mode of development, and microscopic structure, in the vertebrate animals. - i-xl, 113-228, pls 151-189A (not 162A) pp.; Hippolyte Balliere, London.

Owen, R. 1860. On the orders of fossil and recent Reptilia, and their distribution in time. Report of the British Association for the Advancement of Science for 1859 29: 153-166.

Páramo-Fonseca, M.E. 1997. Platypterygius sachicarum (Reptilia, Ichthyosauria) nueva especie del Cretácico de Colombia. Revista Ingeominas 6: 1-12.

Patarroyo, P. 2000. Distribución de amonitas del Barremiano de la Formación Paja en el sector de Villa de Leiva (BoyacáColombia). Bioestratigrafía. Geología Colombiana 25: 149-162.

Patarroyo, P. 2004. Die Entwicklung der Ammoniten der Familie Pulchelliidae aus dem Barrême von Zentral-Kolumbien (Südamerika). Revue de Paléobiologie, Genève 23 (1): 1-65.

Reboulet, S. \& Hoedemaeker, P.J. (Reporters). 2006. Report on the 2nd international meeting of the IUGS lower Cretaceous ammonite working group, the "Kilian Group" (Neuchâtel, Switzerland, 2 september 2005). Cretaceous Research 27: 712-175.

Rock Color Chart Committee. 1963. Geological Rock Color Chart. Geological Society of America (GSA).

Romer, A.S. \& Lewis, A.D. 1959. A mounted skeleton of the giant plesiosaur Kronosaurus. Breviora 112: 1-15.

Sassoon, J., Noè, L.F. \& Benton, M.J. 2012. Cranial anatomy, taxonomic implications and palaeopathology of an upper Jurassic pliosaur (Reptilia: Sauropterygia) from Westbury, Wiltshire, UK. Palaeontology 55 (4): 743-773.

Schumacher, B.A., Carpenter, K \& Everhart, M.J. 2013. A new Cretaceous pliosaurid (Reptilia, Plesiosauria) from the Carlile Shale (Middle Turonian) of Russell County, Kansas. Journal of Vertebrate Paleontology 33 (3): 613-628.

Seeley, H. 1874. Note on some generic modifications of the plesiosaurian pectoral arch. Quarterly Journal of the Geological Society of London 30: 436-449.
Smith, A. S. 2015. Reassessment of 'Plesiosaurus' megacephalus (Sauropterygia: Plesiosauria) from the Triassic-Jurassic boundary, UK. Palaeontologia Electronica 18.1.20A: 1-19.

Sayn, G. 1890. Sur la faune d’Ammonites pyriteuses barrémiennes du Djebel-Ouach, province de Constantine. Extr. Comptes Rendues de l'Académie de Sciences, 1-2, Paris.

Tarlo, L.B. 1959. A review of pliosaurs. In (Hewer, H.R. \& Riley, N.D. eds) Proceedings, XVth International Congress of Zoology, London, 16-23 July 1958. International Congress of Zoology, London.

Tarlo, L.B. 1960. A review of Upper Jurassic pliosaurs. Bulletin of the British Museum of Natural History (Geology) 14 (5): 145-198.

Vermeulen, J. 2003. Étude stratigraphique et paleóntologique de la famille des Pulchelliidae (Ammonoidea, Ammonitina, Endemocerataceae). Géologie Alpine, Mémoire H.S. 42: 1-333, 57pl.

Vermeulen, J. \& Klein J. 2006. Lower Cretaceous Ammonites II: Endemocerataceae: Pulchelliidae, 188-255. In: Riegraf, W.(ed) Fossilium catalogus I: Animalia 141. Backhuys Publishers, Leiden.

Welles, S.P. 1943. Elasmosaurid plesiosaurs with a description of new material from California. Memoirs of the University of California 13: 125-254.

Welles, S.P. 1962. A new species of elasmosaur from the Aptian of Colombia and a review of the Cretaceous plesiosaurs. University of California Publications in Geological Sciences 44 (1): 1-96, pls 1-4.

White, T.E. 1935. On the Skull of Kronosaurus queenslandicus Longman. Occasional Papers of the Boston Society of Natural History 8: 219-228.

Williston, S.W. 1903. North American plesiosaurs, part 1. Publications of the Field Columbian Museum, Geological Series 2: 3-77, pls. 1-29.

Williston, S.W. 1907. The skull of Brachauchenius, with observations on the relationships of the plesiosaurs. Proceedings of the United States National Museum 32: 477-489. 